Check for updates

Cite this: RSC Adv., 2020, 10, 2791

Received 2nd December 2019

Accepted 7th January 2020

DOI: $10.1039 / c 9 r a 10094 f$

rsc.li/rsc-advances

\section{Design, eco-friendly synthesis, molecular modeling and anticancer evaluation of thiazol-5(4H)-ones as potential tubulin polymerization inhibitors targeting the colchicine binding site $\dagger$}

\begin{abstract}
Abeer M. El-Naggar, (D) *a Ibrahim H. Eissa, (D) *c Amany Belal ${ }^{\text {b }}{ }^{\mathrm{b}}$ and Amira A. ElSayed (D) ${ }^{a}$

In recent years, suppressing tubulin polymerization has been developed as a therapeutic approach for cancer treatment. Thus, new derivatives based on thiazol-5(4H)-ones have been designed and synthesized in an eco-friendly manner. The synthesized derivatives have the same essential pharmacophoric features of colchicine binding site inhibitors. The anti-proliferative activity of the new derivatives was evaluated on three human cancer cell lines (HCT-116, HepG-2, and MCF-7) using MTT assay procedure and colchicine was used as a positive control. Compounds $4 \mathrm{f}, 5 \mathrm{a}, 8 \mathrm{f}, 8 \mathrm{~g}$, and $8 \mathrm{k}$ showed superior antiproliferative activities against the three tested cell lines with $\mathrm{IC}_{50}$ values ranging from 2.89 to $9.29 \mu \mathrm{M}$. Further investigation for the most active cytotoxic agents as tubulin polymerization inhibitors was also performed in order to explore the mechanism of their antiproliferative activity. Tubulin polymerization assay results were found to be comperable with the cytotoxicity results. Compounds $4 \mathrm{f}$ and $5 \mathrm{a}$ were the most potent tubulin polymerization inhibitors with an $I_{50}$ value of 9.33 and $9.52 \mathrm{nM}$, respectively. Further studies revealed the ability of 5 a to induce apoptosis and arrest cell cycle growth at the G2/M phase. Molecular docking studies were also conducted to investigate possible binding interactions between the target compounds and the tubulin heterodimer active site. From these studies, it was concluded that inhibition of tubulin polymerization yields the reported cytotoxic activity.
\end{abstract}

\section{Introduction}

Cancer is a complex, widespread, and lethal disease. It begins when cells start to grow beyond their usual boundaries, then can invade adjoining parts of the body and spread to other organs. ${ }^{1}$ Many of the currently available antitumor drugs are unable to differentiate between normal and neoplastic cells, and are also unable to overcome primary or secondary resistance mechanisms evolved in the tumor cells. ${ }^{2,3}$ Thus, there is a pressing need for new antitumor agents with high potency, and less toxicity in non-cancerous cells, that are able to act on unique targets.

Microtubules, the key components of the cytoskeleton are essential in all eukaryotic cells. Microtubules are composed of

${ }^{a}$ Chemistry Department, Faculty of Science, Ain Shams University, Abbassiya, Cairo, 11566, Egypt.E-mail: elsayedam@sci.asu.edu.eg

${ }^{b}$ Medicinal Chemistry Department, Faculty of Pharmacy, Beni-Suef University, BeniSuef 62415, Egypt

'Pharmaceutical Medicinal Chemistry \& Drug Design Department, Faculty of Pharmacy (Boys), Al-Azhar University, Cairo, 11884, Egypt. E-mail: Ibrahimeissa@azhar.edu.eg $\dagger$ Electronic supplementary information (ESI) available. See DOI: $10.1039 / \mathrm{c} 9 \mathrm{ra} 10094 \mathrm{f}$ $\alpha$-tubulin and $\beta$-tubulin heterodimers arranged in the form of slender filamentous tubes that can be many micrometres long. ${ }^{4}$ They are highly dynamic polymers and their polymerization dynamics are tightly regulated both spatially and temporally. ${ }^{5}$ They are crucial in the development and maintenance of cell shape and cell division (mitosis). ${ }^{6}$ During mitosis process, the duplicated chromosomes of a cell are separated into two identical sets before cleavage of the cell into two daughter cells. ${ }^{7}$

The importance of microtubules in mitosis and cell division makes it an important target for anticancer drugs. ${ }^{8}$ Microtubules and their dynamics are considered targets for diverse groups of antimitotic drugs (with various tubulin-binding sites) that have been used with great success in the treatment of cancer. ${ }^{9}$ In view of the success of this class of drugs, it has been argued that microtubules represent the best cancer target to be identified so far, and it seems likely that drugs of this class will continue to be important chemotherapeutic agents, even as more selective approaches are developed ${ }^{10}$

The tubulin heterodimer contains at least three distinct drug binding sites: the paclitaxel (taxanes alkaloid), vinblastine (vinca alkaloid), and colchicine binding sites. ${ }^{11}$ For the first two of these sites, there are many drugs in current use in clinical 
oncology. ${ }^{12,13}$ All the marketed tubulin inhibitors bind to the paclitaxel and vinblastine binding sites are highly potent but the clinical use is limited for several reasons: (i) they are prone to develop multi-drug resistance, (ii) they are highly lipophilic and have to be solubilized by surfactants which can cause hypersensitivity reactions in patients, (iii) they have to be administered intravenously due to poor water solubility which is not convenient for patients and may lead to poor patient compliance. $^{\mathbf{1 4}}$
Tubulin inhibitors that bind to the colchicine binding site can largely overcome the above drawbacks and have therapeutic advantages over taxanes and vinca alkaloids. For example, they can be administered orally owing to the higher water solubility, they do not require surfactants for solubilization, thus are devoid of surfactant-induced hypersensitivity reaction. More importantly they are less prone to develop multi-drug resistance. Therefore, tubulin inhibitors that bind to colchicine binding site have received extraordinary attention in the last ten years. ${ }^{15}$
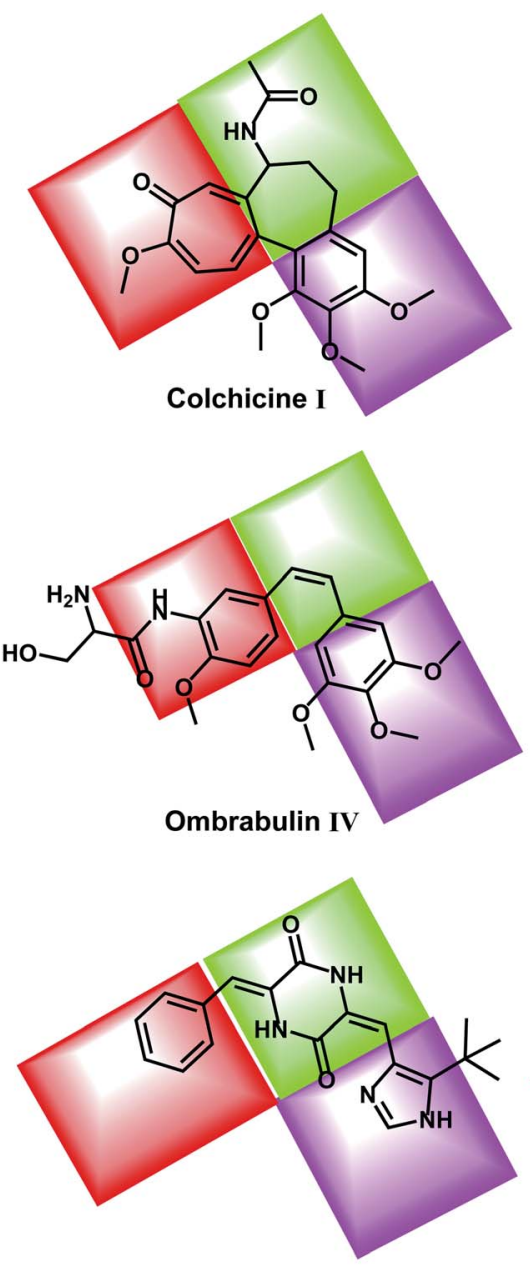

Plinabulin VII
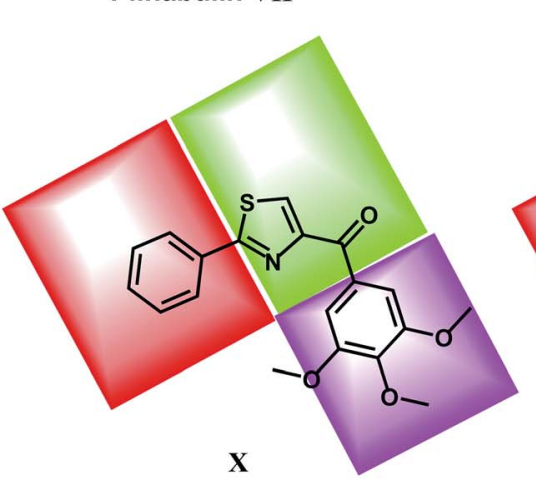
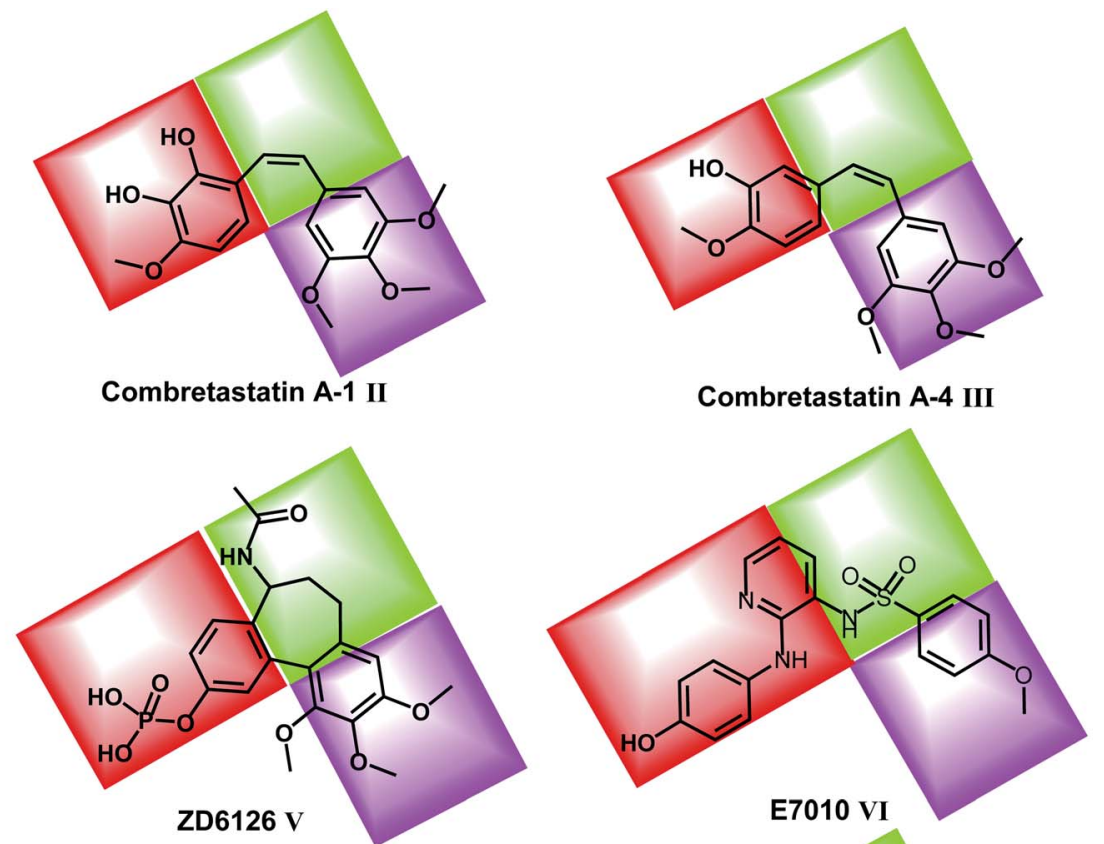

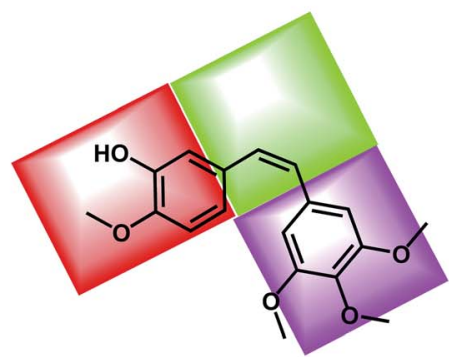

Combretastatin A-4 III
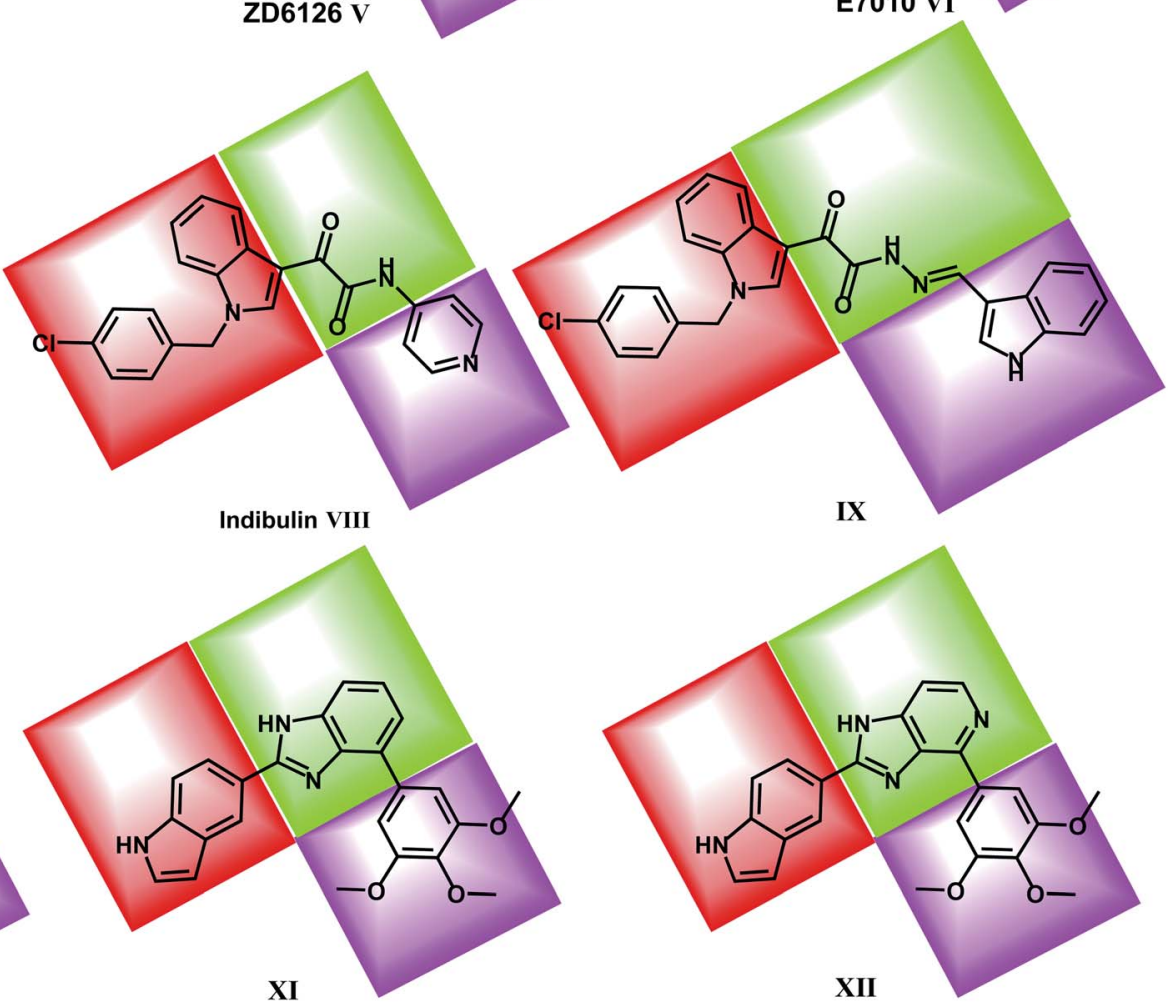

Fig. 1 Reported colchicine binding site inhibitors. 


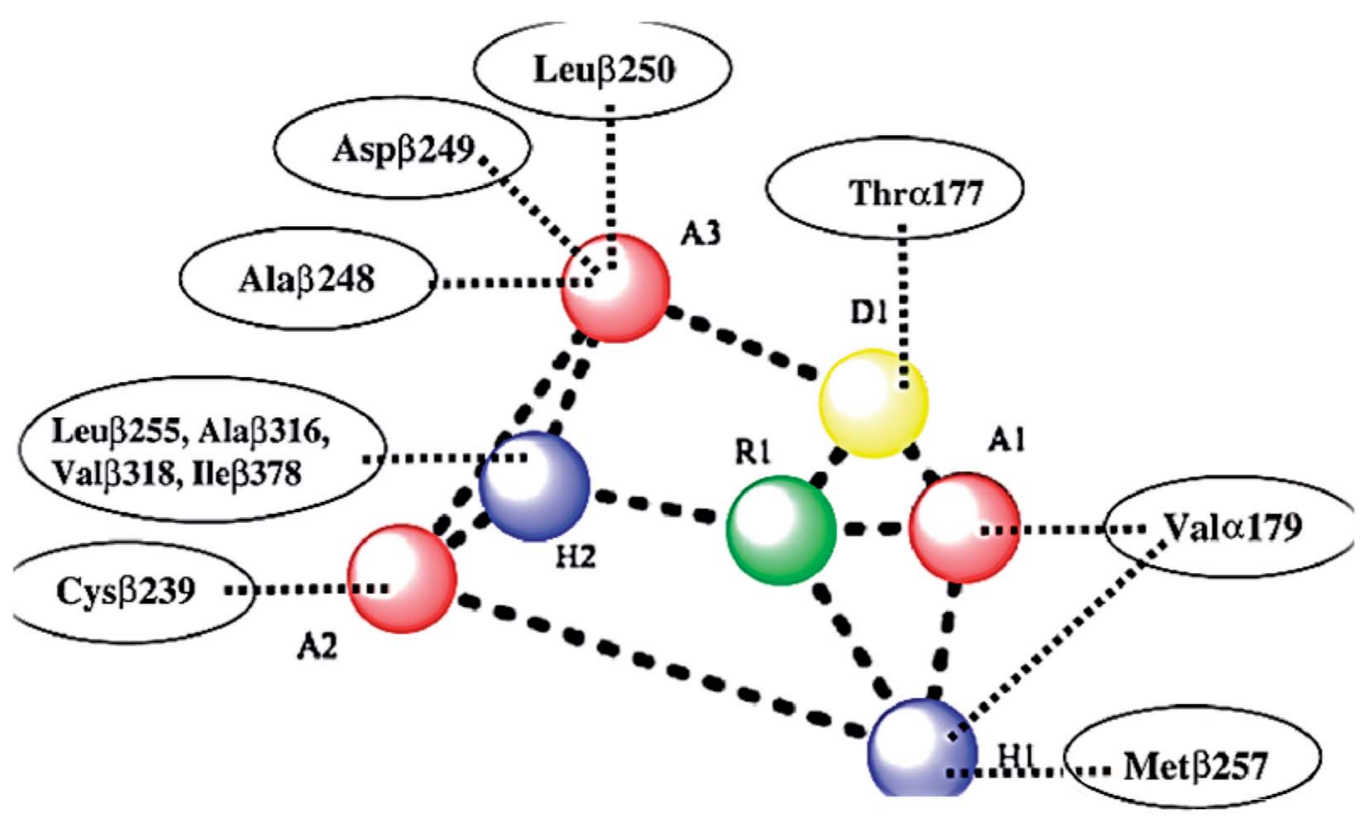

Fig. 2 Seven pharmacophoric features: three hydrogen bond acceptors (A1, A2 \& A3), one hydrogen bond donor (D1), two hydrophobic centers $(\mathrm{H} 1 \& \mathrm{H} 2)$, and one planar group (R1) (based on ref. 14 and 32).

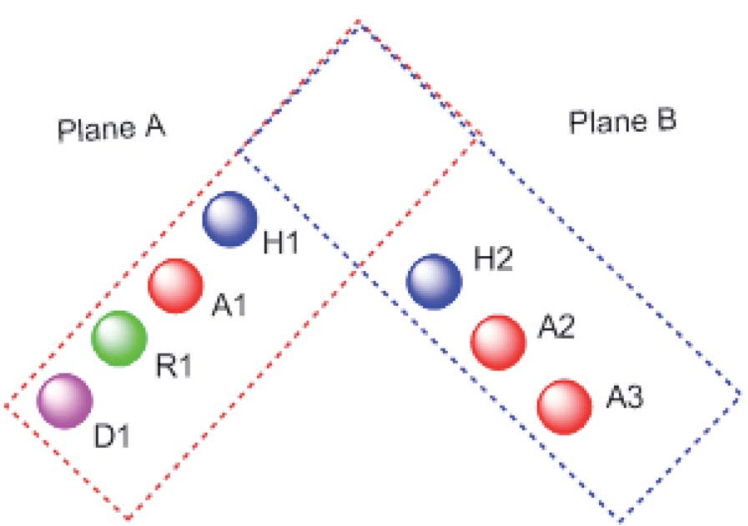

Fig. 3 The pharmacophoric model with two planes: plane A (red) points $A 1, D 1, H 1$ and $R 1$, Plane $B$ (blue) consists of points $A 2, A 3$, and $\mathrm{H} 2$, and (based on ref. 32 ).
Colchicine binding site inhibitors (CBSIs) exert their biological effects by inhibiting tubulin assembly and suppressing microtubule formation. ${ }^{14}$ Colchicine I itself binds to tubulin very tightly, but neither colchicine nor compounds that bind to the colchicine binding site on tubulin have yet found significant use in cancer treatment. ${ }^{16}$ Combretastatin A-1 (CA-1) II and combretastatin A-4 (CA-4) III are two combretastatin analogs, both showed similar microtubule inhibitory activity but have limited water solubility. ${ }^{17}$ In order to improve the water solubility, both compounds were prepared as prodrugs of monosodium phosphate salt, and they can be transformed into the active components CA- 1 and CA- 4 in vivo. ${ }^{18,19}$ In phase II clinical trial, CA-4P showed no bone marrow toxicity, stomatitis, and hair loss. ${ }^{20}$ Ombrabulin IV is another CA-4 analog which has better solubility, oral bioavailability, improved anti-cancer activity and decreased toxicity. ${ }^{14}$

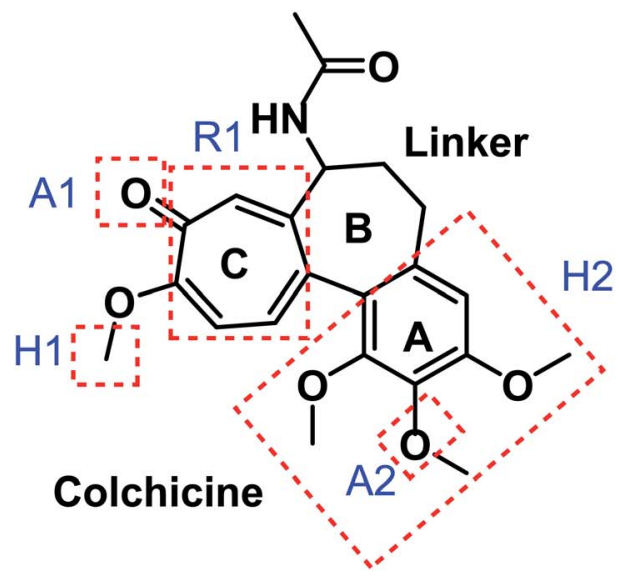

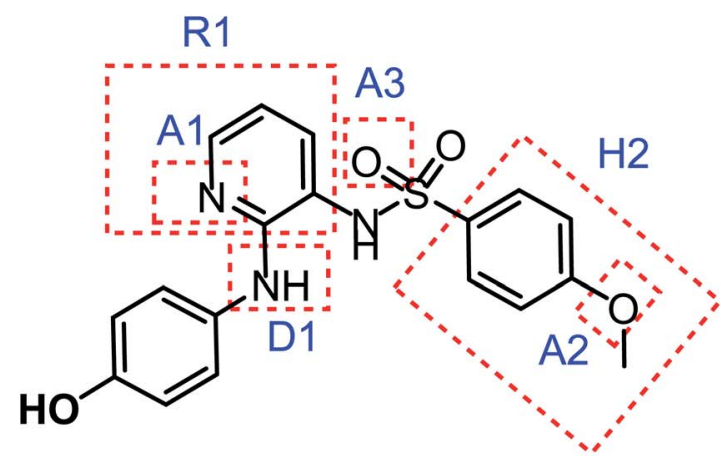

E7010

Fig. 4 Pharmacophoric points of colchicine and E7010 as CBSIs. 

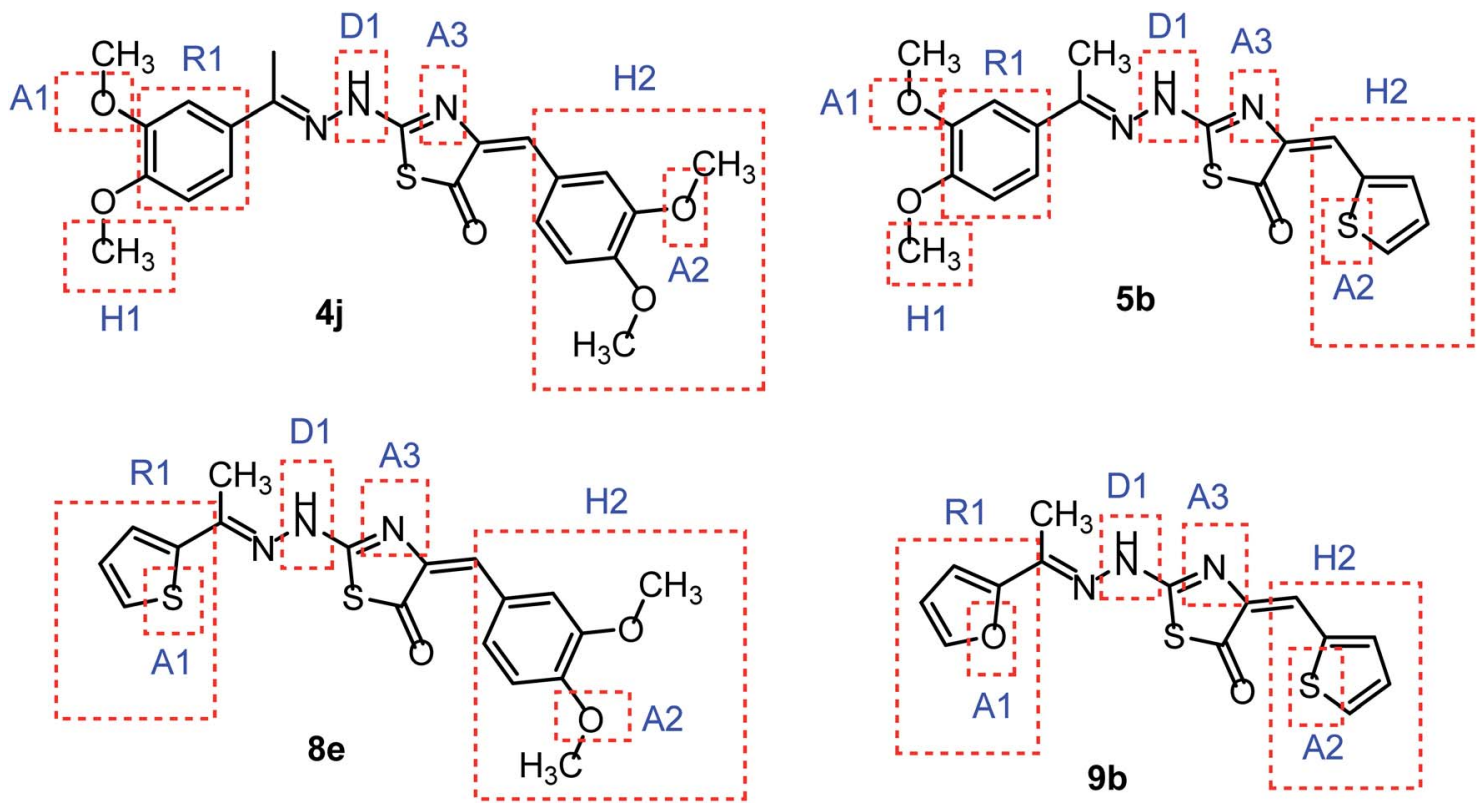

Fig. 5 Some new thiazol-5(4H)-ones having the same essential pharmacophoric features of the reported CBSIs.

ZD6126 V is a NAC ( $N$-acetylcolchicinenol) phosphate prodrug which showed microtubule inhibitory activity in vivo. Moreover, it showed no obvious neurotoxicity and displayed good antitumor activity. ${ }^{21,22}$ E7010 VI is an orally bioavailable sulfonamide that inhibits tubulin polymerization by binding to the colchicine binding site. It exhibited a broad spectrum of antitumor activity in vitro and in vivo. ${ }^{23}$

Plinabulin VII is in a world-wide Phase III clinical trial for non-small cell lung cancer. ${ }^{24}$ Plinabulin blocks the polymerization of tubulin in a unique manner, resulting in multifactorial effects including an enhanced immune-oncology response, ${ }^{25}$ activation of the JNK pathway and disruption of the tumor blood supply. ${ }^{26}$

Indibulin VIII has shown promising anticancer activity with a minimal neurotoxicity in preclinical animal studies and in Phase I clinical trials for cancer chemotherapy. ${ }^{27}$ The antitumor activity of indibulin is believed to be primarily related to its effects on microtubules. ${ }^{28}$

Recently, many molecules (e.g. compounds IX, X, XI \& XII) interacting with the colchicine binding site have been designed and synthesized with significant structural diversity. These
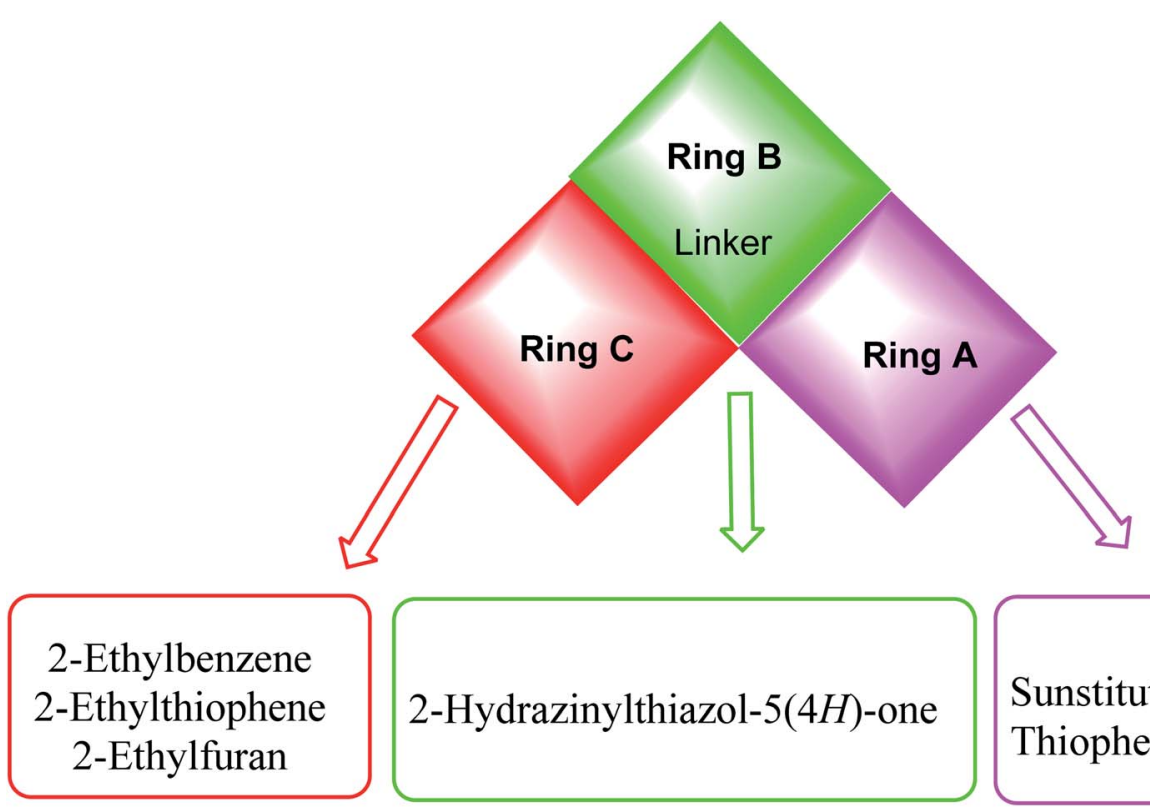

Sunstituted benzylidenes Thiophen-2-ylmethylene

Fig. 6 Summary for the possible modifications of CBSIs. 
compounds were modified and tested in order to find a highly potent, low toxicity agent for treatment of cancers ${ }^{29,30}$ (Fig. 1).

In the present work, our research group synthesized a series of thiazol-5 $(4 H)$-ones having the same pharmacophoric features of CBSIs and targeting the colchicine binding site, to examine their effect as anticancer agents with potential inhibitory effect on tubulin assembly.

\subsection{Rational drug design}

The colchicine binding site is positioned at the interface between the $\alpha$ and $\beta$ subunits of the tubulin protein, with the major part of it buried in the $\beta$ subunit and lined by the helices 7 and 8. The cavity, which is funnel shaped, has a volume of about $600 \mathrm{~A}$ and opens up towards the $\alpha$ subunit of the interface surrounded by residues Asn $101 \alpha$, Thr179 $\alpha$, Ala180 $\alpha$, Val181 $\alpha$, Thr314 $\beta$, Asn349 $\beta$, Asn350 $\beta$, and Lys352 $\beta$. The other, $\beta$ subunit, end of the cavity is surrounded by residues Tyr202 $\beta$, Val238 $\beta$, Thr239 $\beta$, Cys241 $\beta$, Leu242 $\beta$, Leu $248 \beta$, Leu252 $\beta$, Leu255 $\beta$, Ile $378 \beta$, and Val318 $\beta$ and forms the narrow funnel end-like part of the cavity. The predominance of hydrophobic residues confer a strong hydrophobic character to this part of the cavity. At the wider portion, the cavity is surrounded by Ala250 $\beta$, Asp251 $\beta$, Lys254 $\beta$, Asn258 $\beta$, Met259 $\beta$, Ala316 $\beta$, Ala317 $\beta$, Thr353 $\beta$ and Ala354 $\beta$ making it moderately polar/moderately hydrophobic. ${ }^{31}$

As shown in Fig. 2, colchicine binding site inihbitors have the following seven pharmacophoric points: three hydrogen
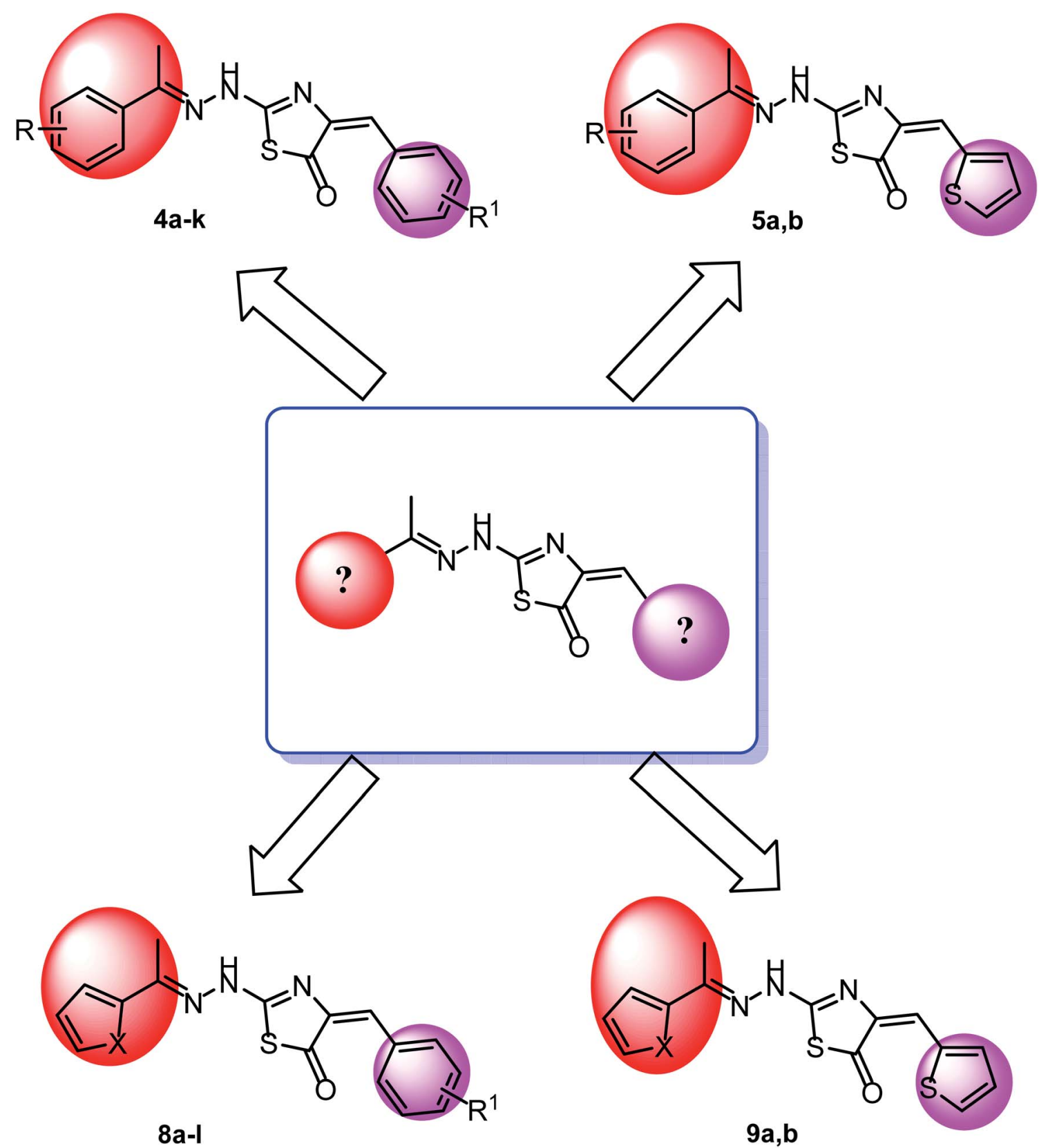

Fig. 7 Rational of molecular design of the new proposed CBSIs. 
bond acceptors (A1, A2, and A3), one hydrogen bond donor (D1), two hydrophobic centers ( $\mathrm{H} 1$ and $\mathrm{H} 2)$ and one planar group (R1). ${ }^{14,32}$ Depending on these previously reported facts we can say that the molecules that will have these seven pharmacophoric features will be considered as promising tubulin inhibitors.

It worth mentioning that, the seven pharmacophoric features can be partitioned among two planes. Features A1, D1, $\mathrm{H} 1$, and $\mathrm{R} 1$ lie in plane $\mathrm{A}$, and features $\mathrm{A} 2, \mathrm{~A} 3$, and $\mathrm{H} 2$ lie in plane B. Relative to one another, the two planes have a tilt of about $45^{\circ}$ and match the shape of the colchicine site ${ }^{32}$ (Fig. 3).

Taking colchicine, as a lead compound for synthesis of the new derivatives, it is formed of three parts: ring $\mathrm{A}$, ring $\mathrm{B}$ (linker), and ring C. Structure-activity study reveals that the A and $\mathrm{C}$ ring of colchicine comprise the minimal structural feature of the molecule needed for its high affinity binding to tubulin. ${ }^{33}$ The changes to the linker region affect the cytotoxic activity of the most reported colchicine binding site inihbitors. ${ }^{34}$ Fig. 4 showed the pharmacophoric points of colchicine and E7010 as representative examples of CBSIs.

In continuation for our previous work of design and synthesis of new anticancer agents, ${ }^{35-45}$ the main target of this work was the synthesis of new thiazol-5(4H)-ones having the same essential pharmacophoric features of the reported CBSIs (Fig. 5). The core of our molecular design rational comprised bioisosteric modification strategies of CBSIs at three different positions.

The first position was the ring A, where different substituted benzylidenes (compounds $\mathbf{4 a}-\mathbf{k} \& \mathbf{8 a}-\mathbf{l}$ ) and thiophen-2ylmethylene moiety (compounds 5a,b \& 9a,b) were used as bioisosteres for ring $\mathrm{A}$. The second position was the ring $\mathrm{C}$, where different substituted 2-ethylbenzene moieties (compounds 4a-k \& 5a,b), 2-ethylthiophene moiety (compounds 8a-1 \& 9a), and 2-ethylfuran moiety (compound 9b) were used as a bioisostere for ring $\mathrm{C}$. The third position was the linker region, where 2-hydrazinylthiazol-5(4H)-one moiety was used to occupy the linker region in all compounds (Fig. 6).

The wide variety of modifications enabled us to study the SAR of these compounds as effective anti-cancer agents with potential tubulin polymerization inhibitory activity which is considered as a crucial objective of our work. All modification pathways and molecular design rationale were illustrated and summarized in Fig. 7.

\section{Results and discussion}

\subsection{Chemistry}

On the bases of green considerations and in continuation of our earlier endeavors ${ }^{\mathbf{4 6}-48}$ toward the development of eco-friendly synthetic routes for heterocyclic systems, we report herein

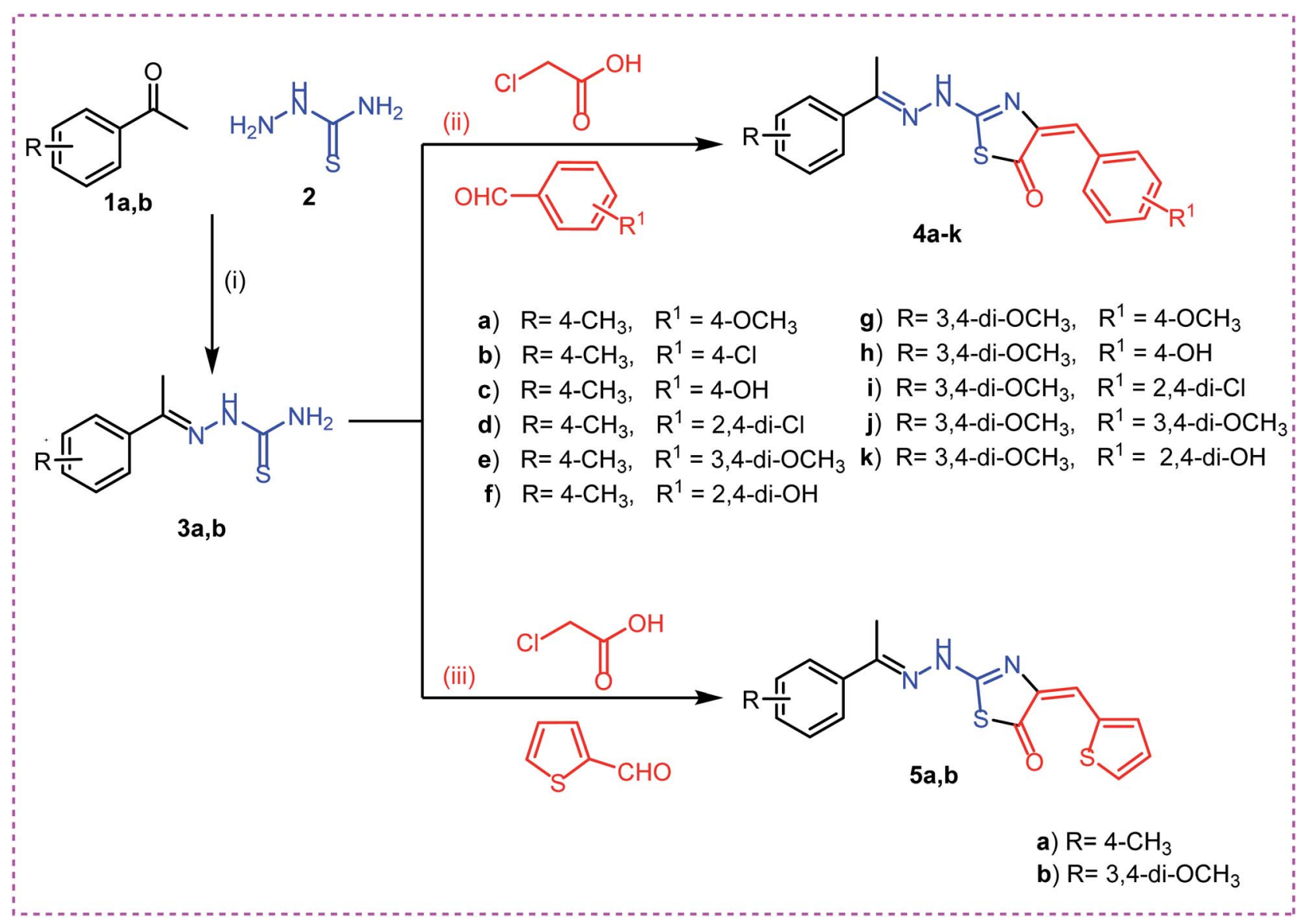

Scheme 1 Synthesis of target compounds $4 \mathrm{a}-\mathrm{k}$ and 5a,b. Reagents and conditions: (i), (ii) and (iii): absolute ethanol and gl. acetic acid/reflux. 
facile routes to various thiazol-5(4H)-one derivatives. In addition to conventional method, ultra-sound irradiation and microwave irradiation (solvent less) techniques were used in the synthesis of the new members. The reactions have been worked well in a one-pot fashion and were completed in a few minutes, with the desired products obtained in good yields.

The synthetic strategies adopted to obtain the target compounds are depicted in (Schemes $1 \& 2$ ). Firstly, refluxing of aryl ketones namely, 4-methyl acetophenone $\mathbf{1 a}$ and 3,4methoxy acetophenone $\mathbf{1 b}$ with thiosemicarbazide $\mathbf{2}$ in absolute ethanol with catalytic amount of glacial acetic acid afforded the key intermediates thiosemicarbazones $\mathbf{3 a}, \mathbf{b}$. Reaction of thiosemicarbazones $\mathbf{3 a} \mathbf{a} \mathbf{b}$ with chloroacetic acid and appropriate substituted aromatic aldehydes namely, 4-methoxy benzaldehyde, 4-chloro benzaldehyde, 4-hydroxy benzaldehyde, 2,4dichloro benzaldehyde, 3,4-dimethoxy benzaldehyde, and 2,4dihydroxy benzaldehyde in ethanol and catalytic amount of glacial acetic acid afforded the target compounds $4 \mathbf{4}-\mathbf{k}$, respectively. Next, reaction of thiosemicarbazones $\mathbf{3 a} \mathbf{a} \mathbf{b}$ with chloroacetic acid and thiophene-2-carbaldehyde in ethanol and catalytic amount of glacial acetic acid afforded the target compounds 5a,b, respectively (Scheme 1).

Secondly, reaction of aryl ketones namely, 2-acetyl thiophene $\mathbf{6 a}$ and 2 -acetyl furan $\mathbf{6 b}$ with thiosemicarbazide $\mathbf{2}$ in absolute ethanol with catalytic amount of glacial acetic acid gave the corresponding thiosemicarbazones 7a,b. Reaction of thiosemicarbazones $\mathbf{7 a , b}$ with chloroacetic acid and appropriate substituted aromatic aldehydes namely, 4-methoxybenzaldehyde, 4-chlorobenzaldehyde, 4-hydroxybenzaldehyde, 2,4-dichlorobenzaldehyde, 3,4-dimethoxybenzaldehyde, and 2,4-dihydroxybenzaldehyde in ethanol and catalytic amount of glacial acetic acid afforded the target compounds $\mathbf{8 a}-\mathbf{l}$, respectively. Next, reaction of thiosemicarbazones $7 \mathbf{a}, \mathbf{b}$ with chloroacetic acid and thiophene-2-carbaldehyde in ethanol and catalytic amount of glacial acetic acid afforded the target compounds 9a,b, respectively (Scheme 2).

Finally, we repeated the two consequence steps of the reaction under both ultrasonic (in ethanol and catalytic amount of acetic acid) and microwave irradiation solvent-free conditions without isolation of the intermediates $\mathbf{3 a}, \mathbf{b}$ and $\mathbf{7 a}, \mathbf{b}$. The reaction mixture afforded the same products with increased yield and shortage in the reaction time under ultrasonic method. Surprisingly, the yield was increased dramatically to $92 \%$.

The structures of the synthesized compounds were established based on spectral data. The IR spectra of compound 3a,b showed the presence of $\mathrm{NH}_{2}$ and $\mathrm{NH}$ absorptions at a range of 3376-3151 $\mathrm{cm}^{-1}$. The ${ }^{1} \mathrm{H}$ NMR spectra of compounds $3 \mathbf{a}, \mathbf{b}$ exhibited singlet signals of methyl group at $2.32 \mathrm{ppm}$, singlet

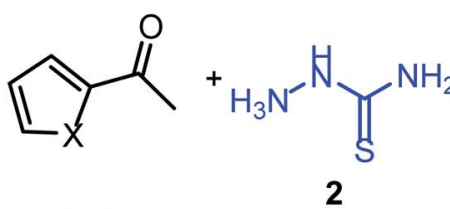

$6 a, b$<smiles></smiles>

$7 a, b$ (ii)

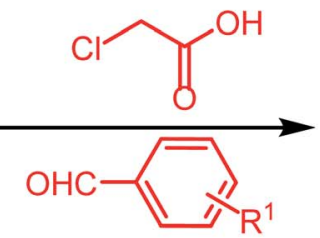

a) $X=S, \quad R^{1}=4-\mathrm{OCH}_{3}$

b) $X=S, \quad R^{1}=4-C l$

c) $X=S, R^{1}=4-O H$

d) $X=S, \quad R^{1}=2,4-d i-C l$

e) $X=S, R^{1}=3,4-$ di- $-\mathrm{OCH}_{3}$

f) $X=S, \quad R^{1}=2,4-d i-O H$

g) $X=O, R^{1}=4-\mathrm{OCH}_{3}$

h) $X=O, R^{1}=4-C l$

i) $X=O, \quad R^{1}=4-O H$

j) $X=O, R^{1}=2,4-d i-C l$

k) $X=0, \quad R^{1}=3,4-d i-O C_{3}$

I) $X=O, \quad R^{1}=2,4-d i-O H$
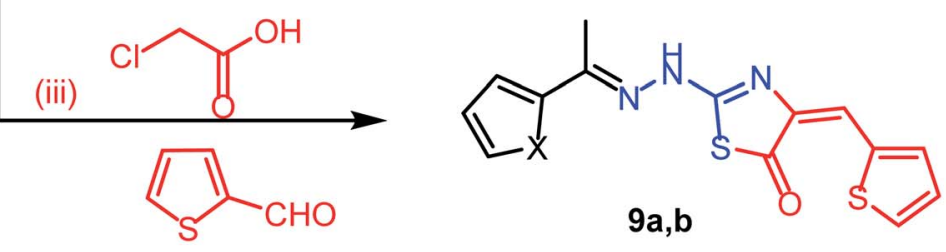

a) $X=S$
b) $X=0$

Scheme 2 Synthesis of target compounds $8 \mathrm{a}-\mathrm{l}$ and 9a,b. Reagents and conditions: (i), (ii) and (iii): absolute ethanol and gl. acetic acid/reflux. 
Table 1 In vitro anti-proliferative activities of the tested compounds and in vitro tubulin polymerization inhibition

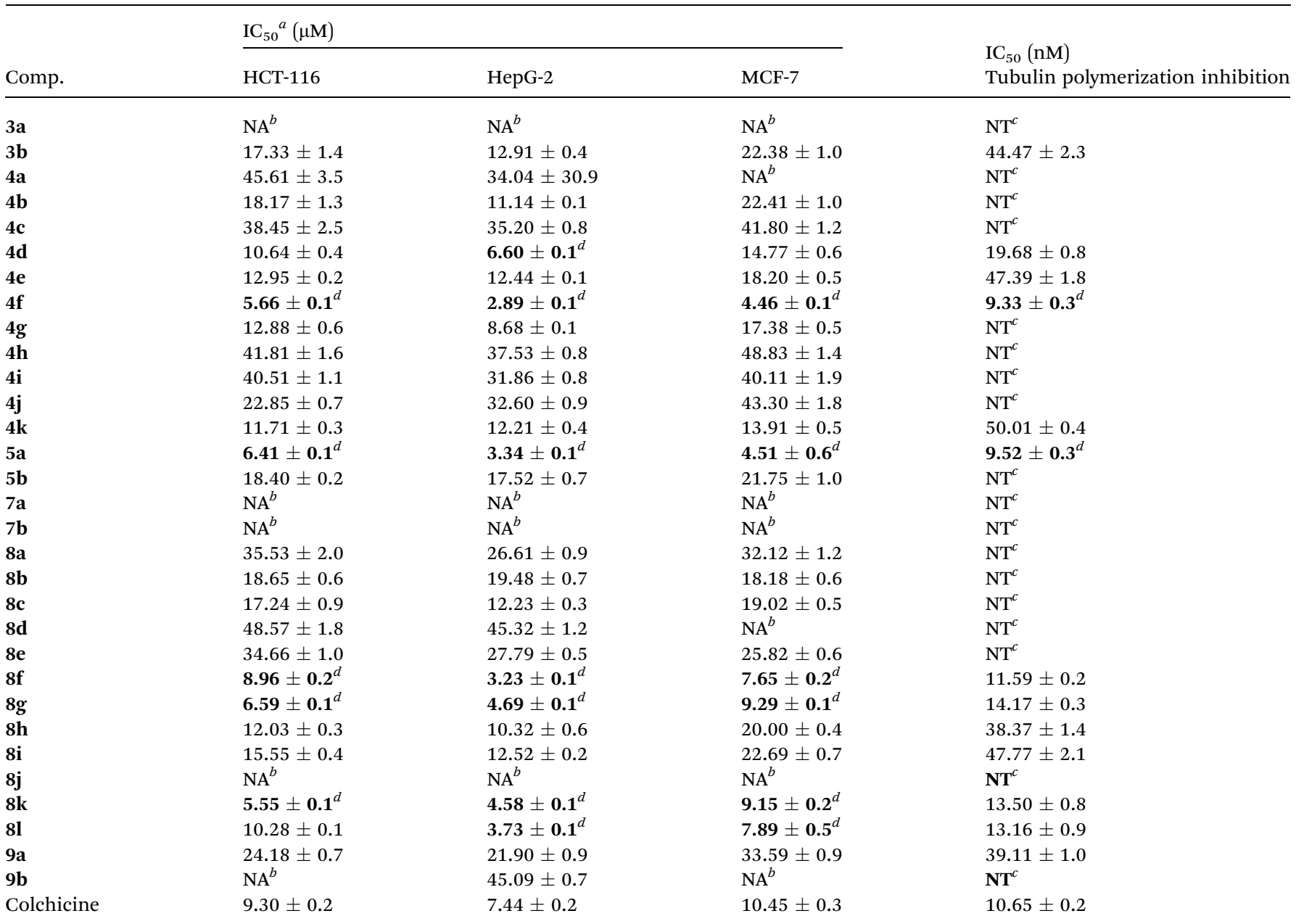

${ }^{a} \mathrm{IC}_{50}$ values are the mean \pm S.D. of three separate experiments. ${ }^{b}$ NA: compounds having $\mathrm{IC}_{50}$ value $>50 \mu \mathrm{M} .{ }^{c}$ NT: compounds not tested for their tubulin polymerization assay. ${ }^{d}$ Bold figures indicate superior potency than colchicine.

signals of $\mathrm{NH}$ group at $8.20 \mathrm{ppm}$, and singlet signals of $\mathrm{NH}_{2}$ at a range of 10.04-10.12 ppm.

For compounds $\mathbf{4 a - k , ~ 5 a , b , ~ 8 a - 1 , ~ a n d ~} \mathbf{9 a}, \mathbf{b}$ the IR spectra showed absorption bands at ranges of 3115-3441, 1688-1722 and 1605-1648 corresponding to $\mathrm{NH}, \mathrm{C}=\mathrm{O}, \mathrm{C}=\mathrm{N}$ groups, respectively. The ${ }^{1} \mathrm{H}$ NMR spectrum of $\mathbf{4 a - k , 5 a , b}, \mathbf{8 a}-\mathbf{l}$, and $\mathbf{9 a}, \mathbf{b}$ showed characteristic peaks attributed to imine methyl protons between $2.47 \mathrm{ppm}$ and $3.92 \mathrm{ppm}$. The proton present in the Schiff base appeared at a range of 8.25-8.66 ppm. The characteristic peaks due to $\mathrm{NH}$ proton appeared between 10.07 and 12.87 ppm as singlet peaks. The ${ }^{13} \mathrm{C}$ NMR spectra of compounds $\mathbf{4 a - k}, \mathbf{5 a}, \mathbf{b}, \mathbf{8 a}-\mathbf{l}$, and $\mathbf{9 a}, \mathbf{b}$ provided additional evidence in support of the proposed structures. All spectra that supports elucidating the chemical structures of the new derivatives are supplied with this research work as ESI file. $\dagger$

\subsection{Biological evaluation}

2.2.1. In vitro anti-proliferative activity. The synthesized compounds were tested for their in vitro cytotoxic activities using standard MTT method, ${ }^{49-51}$ against a group of human cancer cell lines namely; colorectal carcinoma (HCT-116), hepatocellular carcinoma (HepG-2), and breast cancer (MCF7). Colchicine was used as a positive control. The results of cytotoxicity test were reported as growth inhibitory concentration $\left(\mathrm{IC}_{50}\right)$ values and summarized in Table 1.

The tested compounds exhibited different degrees of antiproliferative activities against the three tested cell lines. Their activities range from excellent, good, moderate to weak.

In general, compounds $\mathbf{4 f}, \mathbf{5 a}, \mathbf{8 f}, \mathbf{8 g}$, and $\mathbf{8 k}$ showed superior antiproliferative activities against the three cell lines with $\mathrm{IC}_{50}$

Table 2 Effect of compound 5a on cell cycle progression in HepG-2 cells

\begin{tabular}{lllll}
\hline & \multicolumn{4}{l}{ Cell cycle distribution (\%) } \\
\cline { 2 - 5 } Sample & \% G0-G1 & \% S & \% G2-M & \% Pre-G1 \\
\hline 5a/HepG-2 & 40.17 & 39.28 & 20.55 & 15.33 \\
Cont. HepG-2 & 56.76 & 38.15 & 5.09 & 2.14
\end{tabular}




\section{Cell Cycle Analysis}

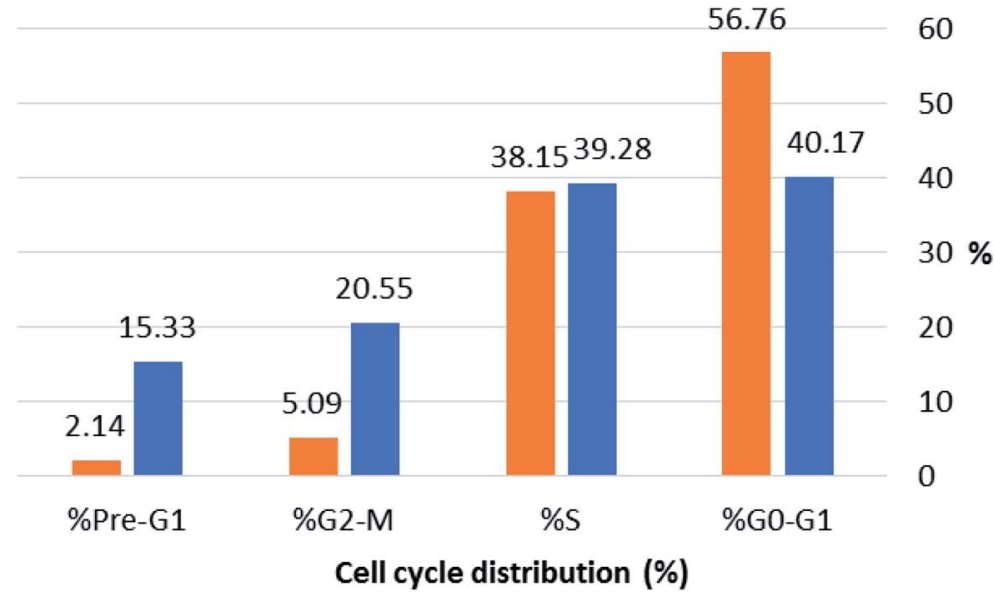

- 5a / HepG-2

Cont. HepG-2

Fig. 8 Cell cycle analysis and apoptosis effect in HepG-2 cell line when treated with compound 5a.

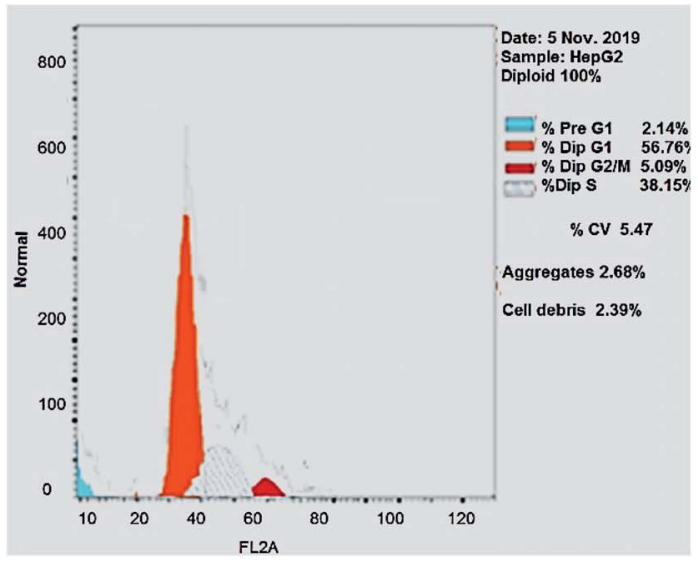

Control

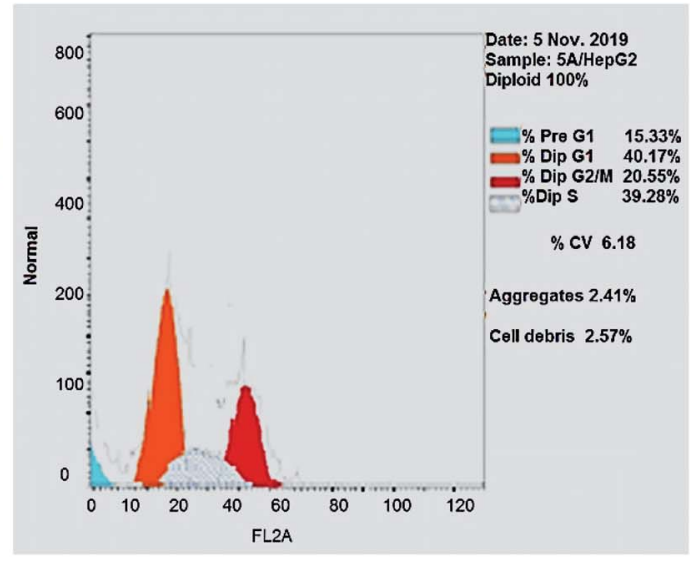

Compound 5a

Fig. 9 HepG-2 cells distribution upon treatment with compound 5 a.

values ranging from 2.89 to $9.29 \mu \mathrm{M}$. The cytotoxic activities of such compounds were higher than that of the reference drug, colchicine $\left(\mathrm{IC}_{50}=9.30,7.44\right.$, and $10.45 \mu \mathrm{M}$ against HCT-116, HepG-2, and MCF-7, respectively). Compound $\mathbf{4 f}$, as representative example, was $1.64,2.57$ and 2.34 times as active as colchicine against HCT-116, HepG-2, and MCF-7, respectively. Also, compound 5a, was 1.45, 2.23 and 2.32 times as active as colchicine against HCT-116, HepG-2, and MCF-7, respectively.

Additionally, compound $\mathbf{8 1}$ exhibited superior activities against HepG-2, and MCF-7 with $\mathrm{IC}_{50}$ values of 3.73 and 7.89 $\mu \mathrm{M}$, respectively, whereas, compound $\mathbf{4 d}$ was higher than colchicine against only HepG-2 cells with $\mathrm{IC}_{50}$ value of $6.60 \mu \mathrm{M}$.

Moreover, several compounds such as $\mathbf{4 e}, \mathbf{4 g}, \mathbf{4 k}, \mathbf{8 b}, \mathbf{8 c}$, and $\mathbf{8 h}$ demonstrated strong anti-proliferative activities over all examined cell lines with $\mathrm{IC}_{50}$ values ranging from 10.32 to 20.00 $\mu \mathrm{M}$. Also, compounds $\mathbf{3 b}, \mathbf{4 b}, \mathbf{4 d}, \mathbf{5 b}$, and $\mathbf{8 i}$ showed strong antiproliferative activities against only two cell lines with $\mathrm{IC}_{50}$ values ranging from 10.64 to $18.40 \mu \mathrm{M}$.
Additionally, compounds $\mathbf{4 b}, \mathbf{4 j}, \mathbf{5 b}, \mathbf{8 a}, \mathbf{8 e}, \mathbf{8} \mathbf{i}$, and $\mathbf{9 a}$ displayed moderate anti-proliferative activities against at least one cell line with $\mathrm{IC}_{50}$ values ranging from 21.90 to $27.79 \mu \mathrm{M}$.

On the other hand, compounds $4 \mathbf{a}, 4 \mathbf{c}, 4 \mathbf{h}, 4 \mathbf{i}, 4 \mathbf{j}, 8 \mathbf{a}$, and $8 \mathbf{d}$ displayed weak anti-proliferative activities against at least two cell lines with $\mathrm{IC}_{50}$ values ranging from 31.86 to $48.83 \mu \mathrm{M}$.

Finally, compounds $\mathbf{3 a}, \mathbf{7 a}, \mathbf{7 b}$, and $\mathbf{8 j}$ showed no activity against any of the tested cancer cell lines. In addition,

Table 3 Apoptosis and necrosis percent induced by compound $5 \mathrm{a}$ in HepG-2 cells

\begin{tabular}{lllll}
\hline & \multicolumn{2}{c}{ Apoptosis } & & \\
\cline { 2 - 4 } Sample & Total & Early & Late & Necrosis \\
\hline 5a/HepG-2 & 15.33 & 8.25 & 5.54 & 1.54 \\
Cont. HepG-2 & 2.14 & 1.02 & 0.64 & 0.48
\end{tabular}


Apoptosis Analysis

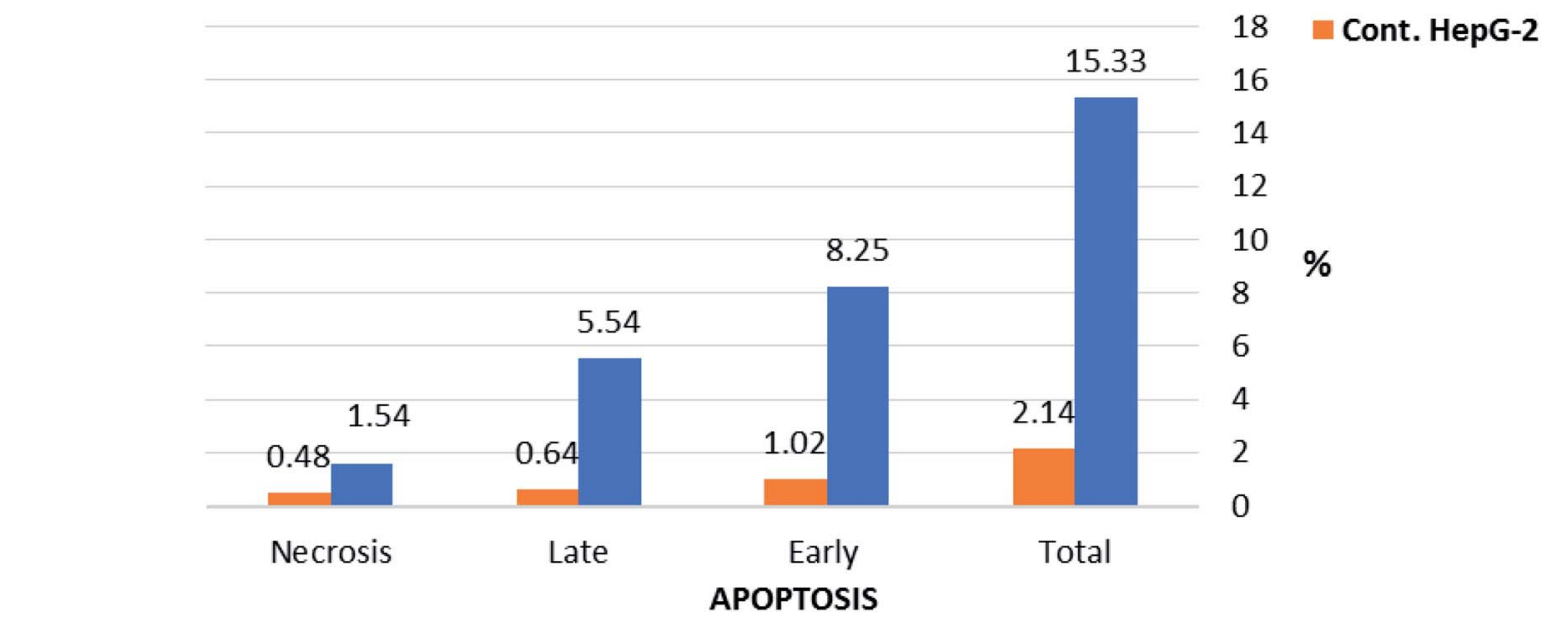

5a / HepG-2

Cont. HepG-2

Fig. 10 Percentage of induced cell death by compound 5a on HepG-2 cells.

compound 9b was inactive against HCT-116 and MCF-7 and compounds $\mathbf{4 a}, \mathbf{8 d}$ revealed to be inactive against MCF-7 only.

2.2.2. Tubulin polymerization assay. To investigate whether the cytotoxic activity of the synthesized compounds was related to an interaction with the tubulin system, an in vitro tubulin polymerization assay was performed for the most cytotoxic members. The inhibition assay on microtubule polymerization was evaluated turbidimetrically using a fluorescent plate reader. ${ }^{52}$ Colchicine was used as a positive control (Table 1).

Compounds $\mathbf{4 f}$ and $\mathbf{5 a}$ were the most potent tubulin polymerization inhibitors with an $\mathrm{IC}_{50}$ values of 9.33 and $9.52 \mathrm{nM}$, respectively. These compounds had activities higher than that of colchicine $\left(\mathrm{IC}_{50}=10.65 \mathrm{nM}\right)$. Additionally, compounds 8f, 8k, and $\mathbf{8 1}$ showed promising activities nearly equal to colchicine with $\mathrm{IC}_{50}$ values of $11.59,13.50$, and $13.16 \mathrm{nM}$, respectively. Also, compounds $\mathbf{4 d}$ and $\mathbf{8 g}$ showed strong tubulin polymerization inhibitory activities with $\mathrm{IC}_{50}$ values of 19.68 and $14.17 \mathrm{nM}$, respectively. Finally, compounds $\mathbf{3 b}, \mathbf{4 e}, \mathbf{4 k}, \mathbf{8 h}$, $\mathbf{8 i}$ and $9 \mathbf{a}$ exhibited moderate tubulin polymerization inhibitory activities with $\mathrm{IC}_{50}$ values ranging from 38.37 to $50.01 \mathrm{nM}$. The results strongly implicated a direct interaction between the examined compounds and tubulin. It can be concluded that the cytotoxic activity of the synthesized compounds may derive from an interaction with tubulin and an interference with microtubule assembly.

2.2.3. Cell cycle analysis. To gain a better insight into the impact of compound 5a on cancer cell growth inhibition, its impact on cell cycle distribution and apoptosis induction was assessed using HepG-2 cells according to the method outlined by Wang et $a{ }^{.53}$ In fact, anticancer agents hinder cancer cell growth and multiplication by arresting cell division at distinct checkpoints, and that cells resist apoptosis are highly resistant to cancer treatment. ${ }^{54}$ In the present work, HepG-2 cell line was

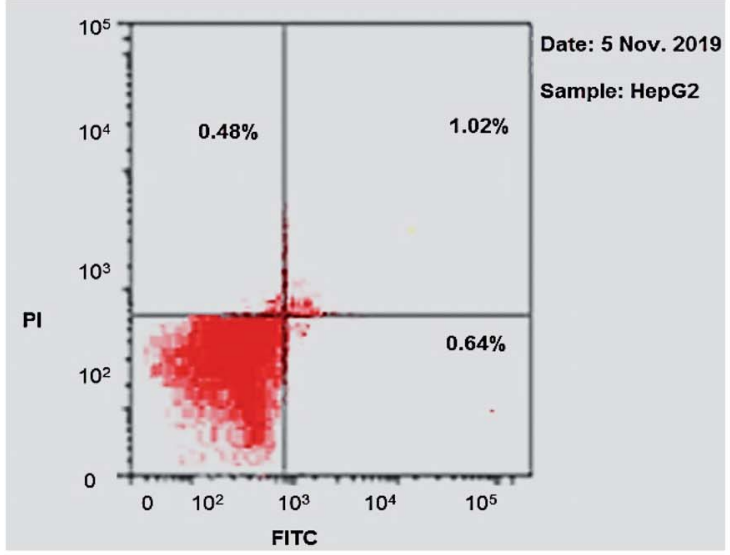

Control

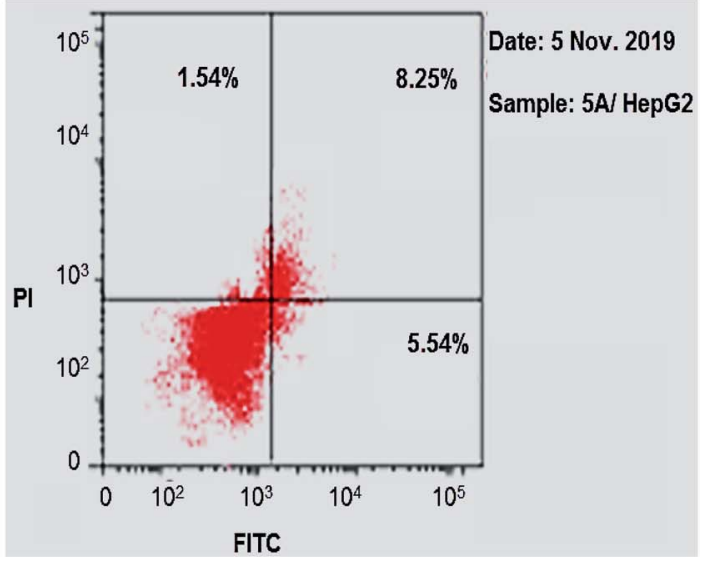

Compound 5a

Fig. 11 Induced apoptosis on HepG-2 cells by compound 5 a. 


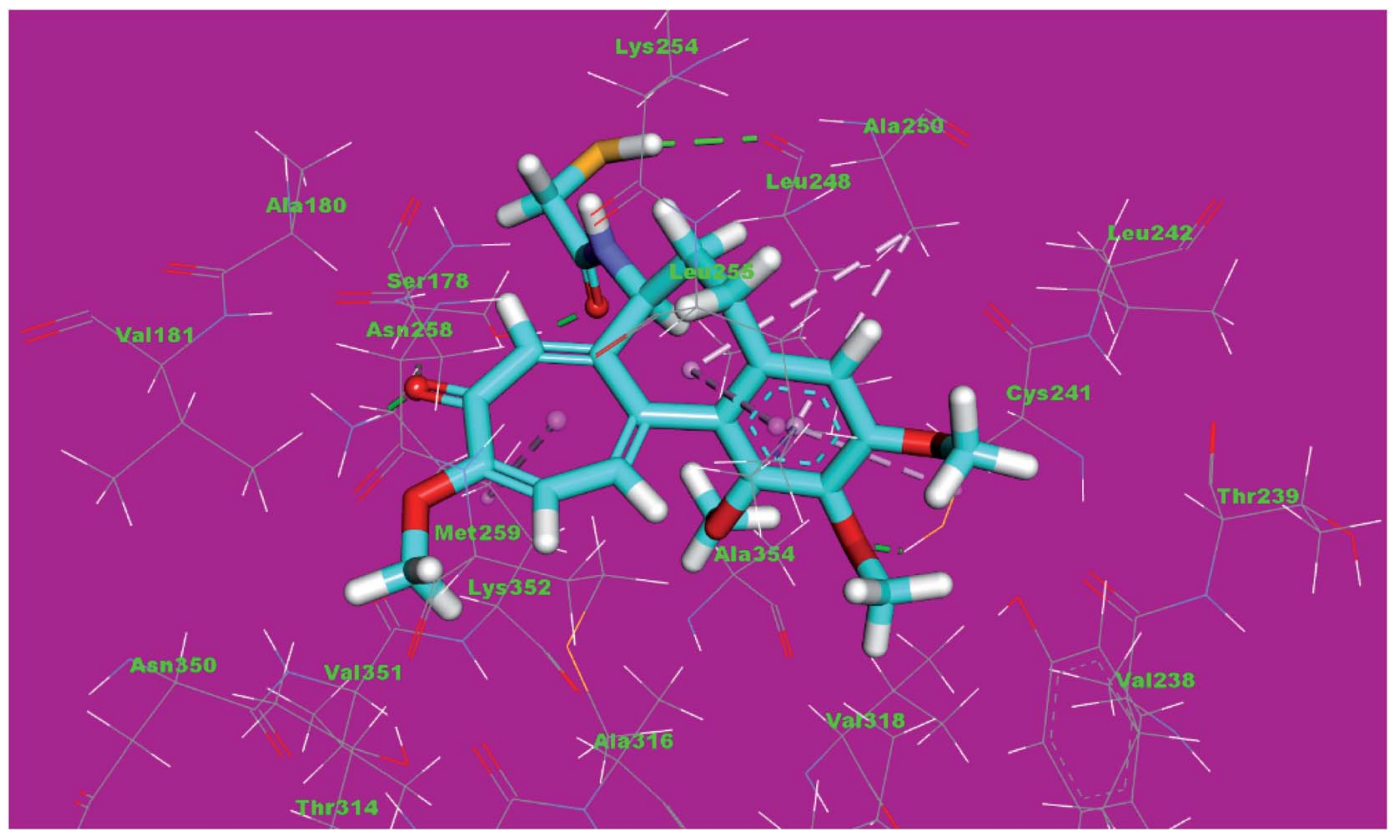

Fig. 12 3D structure of co-crystallized ligand, DAMA-colchicine, docked into the active site of tubulin.

treated with compound $\mathbf{5 a}$ at a concentration equals its $\mathrm{IC}_{50}$ value on tubulin $(9.52 \mathrm{nM})$ for $24 \mathrm{~h}$.

As shown in Table 2, Fig. 8 and 9, the percentage of HepG-2 cells at S phase was increased from $38.15 \%$ to $39.28 \%$ after incubation with compound 5a. Additionally, cells in G2/M phase markedly increased from $5.09 \%$ to $20.55 \%$ and the G1 phase decreased from $56.76 \%$ in control to $40.17 \%$, indicating that compound 5a caused cell arrest at G2/M phase. Also, it was found that the cells increased from $2.14 \%$ to $15.33 \%$ at pre-G1 phase, indicating that compound 5a caused apoptosis at preG1 phase.

2.2.4. Annexin V-FITC apoptosis assay. To further confirm Apoptotic effect of compound 5a in HepG-2 cells, Annexin V and PI double staining assay was performed. ${ }^{55}$ In this test, HepG-2 cells were incubated with compound $\mathbf{5 a}$ at concentration of 2.5 $\mu \mathrm{M}$ for $24 \mathrm{~h}$. The results were reported in Table 3, Fig. 10 and 11 .

The results revealed that compound $5 \mathrm{a}$ induced total apoptotic effect equal $13.79 \%$ which was eight time more than

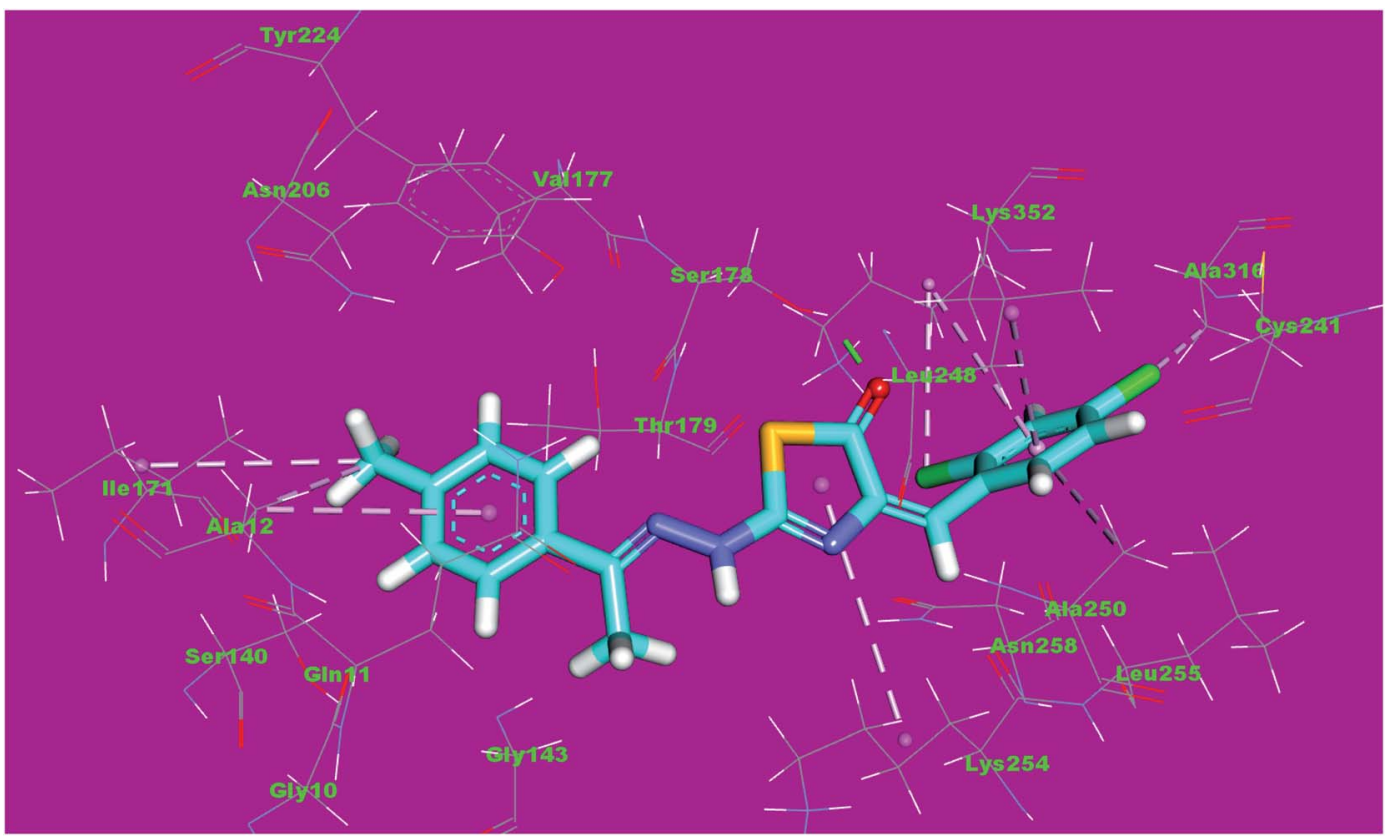

Fig. 13 3D structure of compound $4 d$ docked into the active site of tubulin. 


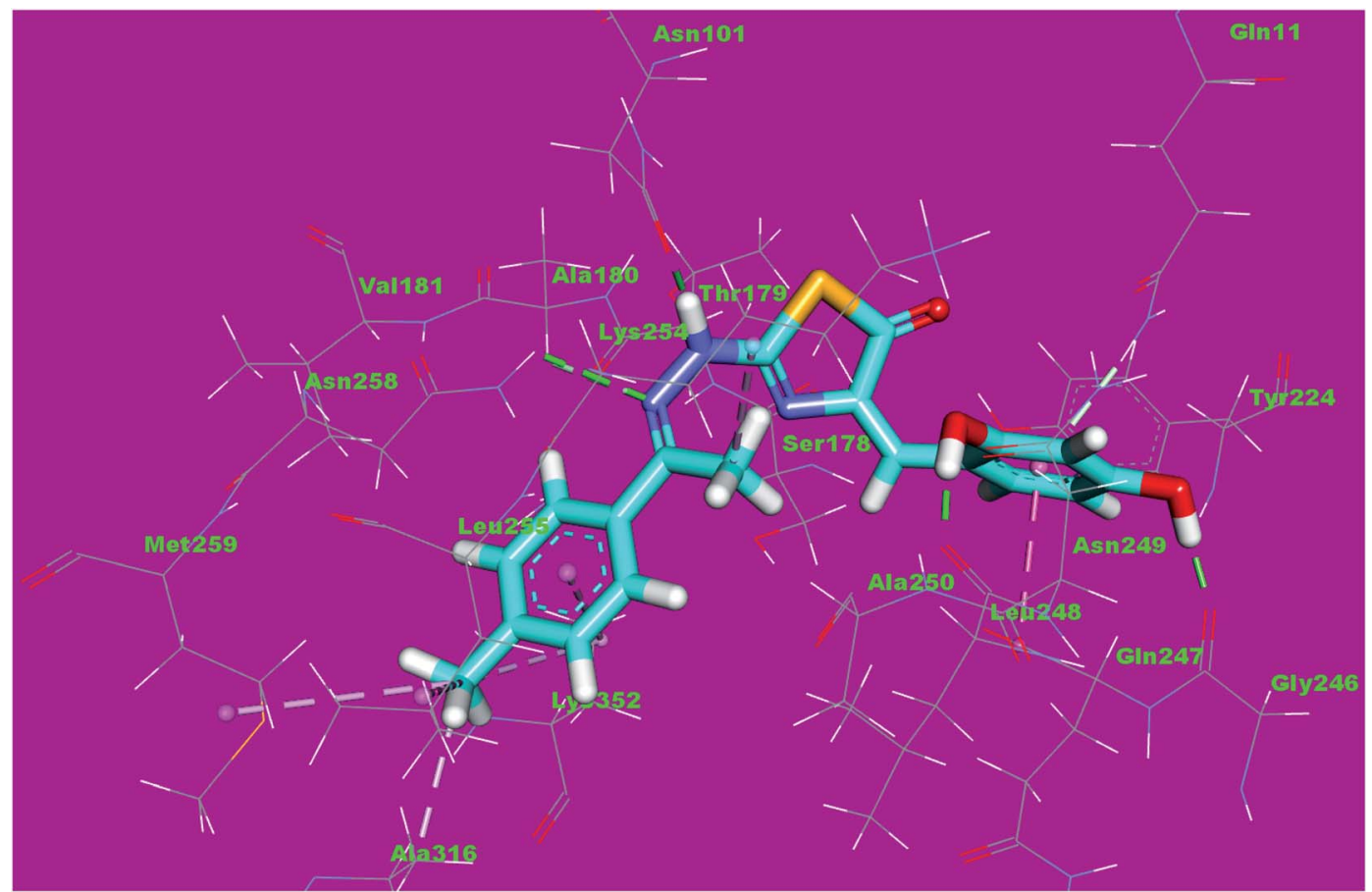

Fig. 14 3D structure of compound $4 \mathrm{f}$ docked into the active site of tubulin.

the control (1.66\%). In details, compound 5a obviously induced early apoptosis by $8.25 \%$ and enhanced late apoptosis by $5.54 \%$ when compared with the untreated control HepG-2 cells $(1.02 \%$ and $0.64 \%$, respectively).

\subsection{Docking studies}

Molecular docking studies were conducted to give a guidance of molecular binding modes of the tested molecules inside the pocket of tubulin heterodimers. The selected compounds have been docked against tubulin heterodimers using MOE2014 to determine the free energy and binding mode. The selection of the most promising molecules depended on the rightbinding mode and the binding free energy $(\Delta G){ }^{56}$

The binding free energies of the synthesized compounds and the reference ligand were summarized in Table 4 . The binding mode of the co-crystallized ligand, DAMA-colchicine, exhibited

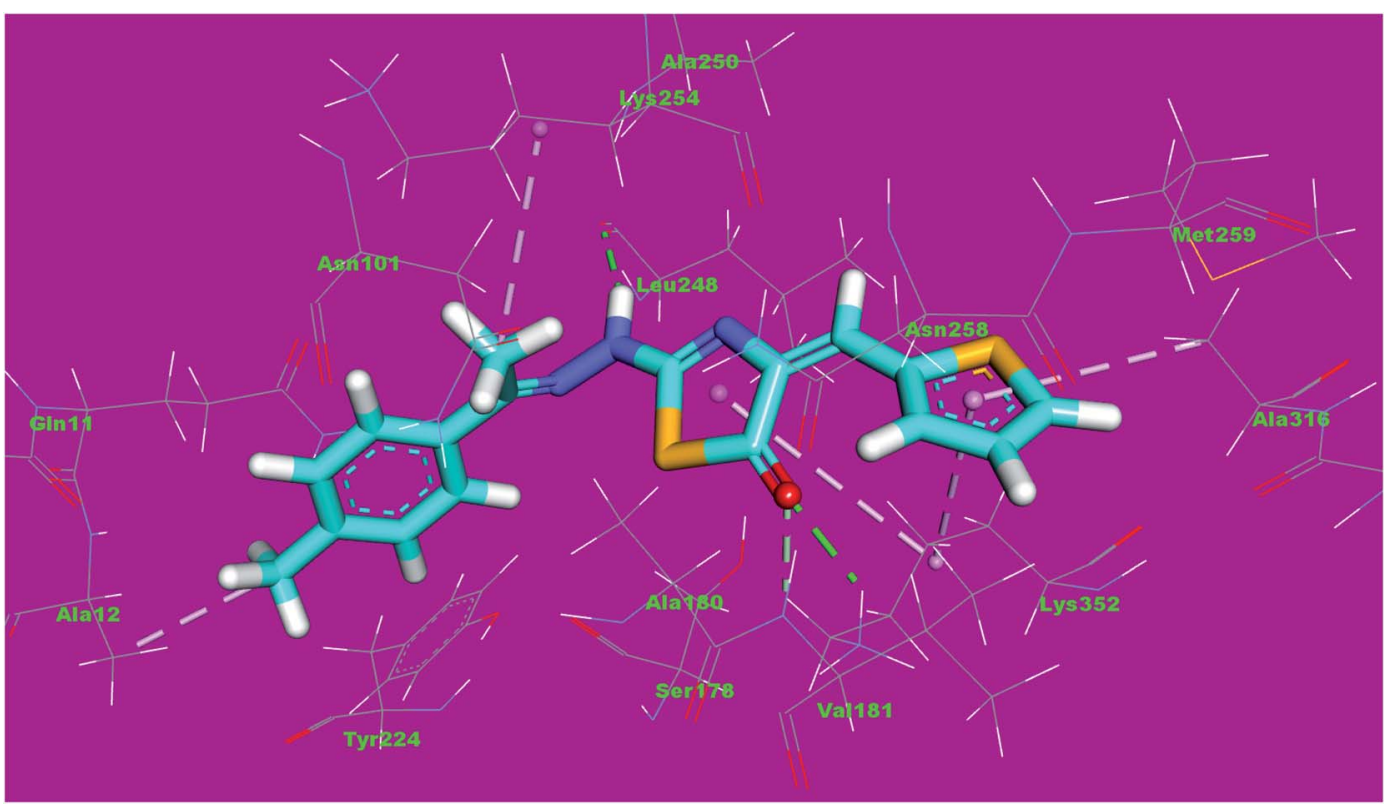

Fig. 15 3D structure of compound 5a docked into the active site of tubulin. 


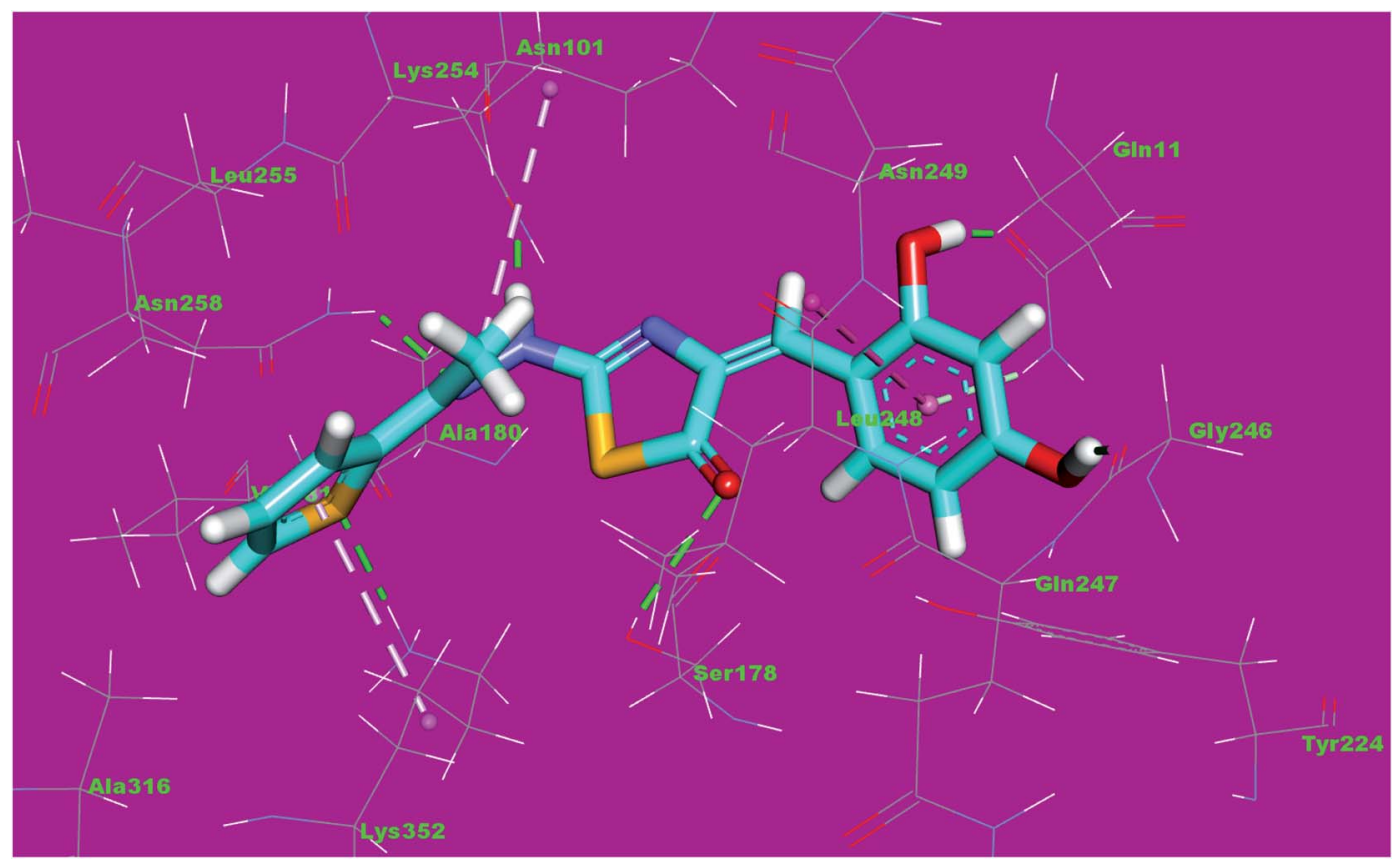

Fig. 16 3D structure of compound $8 f$ docked into the active site of tubulin.

an energy binding of $-13.08 \mathrm{kcal} \mathrm{mol}^{-1}$. The ring A (trimethoxy phenyl moiety) formed a hydrogen bond with Cys241. Also, it formed five hydrophobic interactions with Ala250, Leu255 and Cys241. The 2-mercaptoacetamide moiety formed two hydrogen bonds with Leu248 and Ser178. The ring C formed one hydrogen bonding and one hydrophobic interaction with Lys352 (Fig. 12).

Compound $\mathbf{4 d}$ as a representative example showed a binding mode like that of DAMA-colchicine, with affinity value of $-11.44 \mathrm{kcal} \mathrm{mol}^{-1}$. The 2,4-dichlorophenyl moiety formed five hydrophobic interactions with Ala316, Lys352, Leu248 and Ala250. The thiazol moiety formed one hydrogen bond with Ser178 and one hydrophobic interaction with Lys254. The $p$ tolyl moiety formed three hydrophobic interactions with Ile171 and Ala12 (Fig. 13).

The binding mode of compound $\mathbf{4 f}$ exhibited an affinity value of $-11.80 \mathrm{kcal} \mathrm{mol}^{-1}$. The 2,4-dihydroxybenzyl moiety formed two hydrogen bonds with Gly246 and Leu248. Also, it formed two hydrophobic interactions with Gln247 and Gln11. The hydrazinyl moiety formed two hydrogen bonds with Asn258 and Asn101. The $p$-tolyl moiety formed five hydrophobic interactions with Leu255, Met259, Ala316, and Lys352 (Fig. 14).

The binding mode of compound 5a exhibited an affinity value of $-10.41 \mathrm{kcal} \mathrm{mol}^{-1}$. The thiophene moiety formed two hydrophobic interactions with Ala316 and Lys352. The hydrazinylthiazol moiety formed two hydrogen bonds with Lys352 and Lys254. Also, it formed one hydrophobic interaction with Lys352. The $p$-tolyl moiety formed one hydrophobic interaction with Ala12 (Fig. 15).

The binding mode of compound 8 f exhibited an affinity value of $-13.19 \mathrm{kcal} \mathrm{mol}^{-1}$. The 2,4-dihydroxyphenyl moiety formed two hydrogen bonds with Gln11 and Gly246. In addition, it formed one hydrophobic interaction with Leu248. The hydrazinylthiazol moiety formed three hydrogen bonds with Ser178, Asn101 and Asn258. The thiophene moiety formed one hydrophobic interaction and one hydrogen bond with Lys352 (Fig. 16).

\subsection{Structure-activity relationship (SAR)}

As outlined in the rationale molecular design, it was aimed at studying the SAR of the newly synthesized thiazol-5 $(4 \mathrm{H})$-one derivatives as potential tubulin polymerization inhibitors.

Initially, the effect of the ring A on the activity was explored. Comparing the cytotoxic activity of compounds 5a incorporating thiophen-2-ylmethylene as a ring A with compounds $\mathbf{4 f}$ incorporating substituted benzylidenes as a ring A, indicated

Table 4 The docking binding free energies of the synthesized and cocrystallized ligand (DAMA-colchicine) compounds against tubulin

\begin{tabular}{llll}
\hline & $\begin{array}{l}\text { Binding free } \\
\text { energy }\left(\mathrm{kcal} \mathrm{mol}^{-1}\right)\end{array}$ & $\begin{array}{l}\text { Binding free } \\
\text { energy }\left(\mathrm{kcal} \mathrm{mol} \mathrm{mol}^{-1}\right)\end{array}$ \\
\hline $\mathbf{4 a}$ & -9.67 & $\mathbf{8 b}$ & -10.18 \\
$\mathbf{4 b}$ & -10.72 & $\mathbf{8 c}$ & -10.08 \\
$\mathbf{4 c}$ & -9.35 & $\mathbf{8 d}$ & -11.11 \\
$\mathbf{4 d}$ & -11.44 & $\mathbf{8 e}$ & -13.19 \\
$\mathbf{4 e}$ & -12.44 & $\mathbf{8 f}$ & -9.99 \\
$\mathbf{4 f}$ & -11.80 & $\mathbf{8 g}$ & -11.00 \\
$\mathbf{4 g}$ & -12.55 & $\mathbf{8 h}$ & -10.31 \\
$\mathbf{4 h}$ & -12.22 & $\mathbf{8 i}$ & -10.02 \\
$\mathbf{4 i}$ & -12.53 & $\mathbf{8 j}$ & -10.98 \\
$\mathbf{4 j}$ & -12.20 & $\mathbf{8 k}$ & -12.28 \\
$\mathbf{4 k}$ & -14.35 & $\mathbf{8 L}$ & -10.15 \\
$\mathbf{5 a}$ & -10.41 & $\mathbf{9 a}$ & -9.26 \\
$\mathbf{5 b}$ & -12.71 & $\mathbf{9 b}$ & -10.52 \\
$\mathbf{8 a}$ & -10.48 & DAMA-colchicine & -13.08
\end{tabular}


Table 5 Reaction time and yield of both conventional, ultrasonic and microwave assisted synthesis of the synthesized compounds

\begin{tabular}{|c|c|c|c|c|c|c|}
\hline \multirow[b]{2}{*}{ Comp. } & \multicolumn{3}{|c|}{ Time (min) } & \multicolumn{3}{|c|}{ Yield } \\
\hline & $\mathrm{C}^{a}$ & $\mathrm{US}^{a}$ & $\mathrm{MW}^{a}$ & $\mathrm{C}^{a}$ & $\mathrm{US}^{a}$ & $\mathrm{MW}^{a}$ \\
\hline $4 a$ & $180+240$ & $10+15$ & $2+2$ & 55 & 77 & 88 \\
\hline $4 \mathrm{~b}$ & $180+240$ & $10+15$ & $2+2$ & 54 & 79 & 90 \\
\hline $4 c$ & $180+240$ & $10+15$ & $2+2$ & 56 & 77 & 88 \\
\hline $4 d$ & $180+240$ & $10+15$ & $2+2$ & 54 & 66 & 90 \\
\hline $4 e$ & $180+240$ & $10+15$ & $2+2$ & 57 & 60 & 92 \\
\hline 4f & $180+240$ & $10+15$ & $2+2$ & 49 & 62 & 93 \\
\hline $4 \mathrm{~g}$ & $180+240$ & $10+15$ & $2+2$ & 58 & 67 & 92 \\
\hline $4 \mathrm{~h}$ & $180+240$ & $10+15$ & $2+2$ & 55 & 78 & 90 \\
\hline $4 \mathrm{i}$ & $180+240$ & $10+15$ & $2+2$ & 53 & 62 & 95 \\
\hline $4 j$ & $180+240$ & $10+15$ & $2+2$ & 56 & 78 & 91 \\
\hline $4 \mathbf{k}$ & $180+240$ & $10+15$ & $2+2$ & 50 & 77 & 88 \\
\hline $5 \mathbf{a}$ & $180+240$ & $10+15$ & $2+2$ & 57 & 68 & 92 \\
\hline $5 \mathbf{b}$ & $180+240$ & $10+15$ & $2+2$ & 60 & 77 & 93 \\
\hline $8 \mathbf{a}$ & $180+240$ & $10+15$ & $2+2$ & 62 & 79 & 94 \\
\hline $8 b$ & $180+240$ & $10+15$ & $2+2$ & 56 & 71 & 93 \\
\hline $8 c$ & $180+240$ & $10+15$ & $2+2$ & 54 & 62 & 95 \\
\hline 8d & $180+240$ & $10+15$ & $2+2$ & 55 & 78 & 91 \\
\hline $8 \mathrm{e}$ & $180+240$ & $10+15$ & $2+2$ & 51 & 77 & 88 \\
\hline $8 f$ & $180+240$ & $10+15$ & $2+2$ & 52 & 79 & 90 \\
\hline $8 \mathrm{~g}$ & $180+240$ & $10+15$ & $2+2$ & 56 & 79 & 90 \\
\hline $8 \mathrm{~h}$ & $180+240$ & $10+15$ & $2+2$ & 50 & 70 & 92 \\
\hline $8 \mathrm{i}$ & $180+240$ & $10+15$ & $2+2$ & 53 & 73 & 93 \\
\hline $8 \mathrm{j}$ & $180+240$ & $10+15$ & $2+2$ & 55 & 67 & 90 \\
\hline $8 k$ & $180+240$ & $10+15$ & $2+2$ & 45 & 69 & 95 \\
\hline 81 & $180+240$ & $10+15$ & $2+2$ & 54 & 78 & 91 \\
\hline $9 a$ & $180+240$ & $10+15$ & $2+2$ & 60 & 60 & 90 \\
\hline $9 b$ & $180+240$ & $10+15$ & $2+2$ & 61 & 77 & 94 \\
\hline
\end{tabular}

${ }^{a} \mathrm{C}$ : conventional, US: ultrasonic, MW: microwave.

that the substituted benzylidenes is more advantageous than thiophen-2-ylmethylene moiety. For the substituted benzylidenes, the cytotoxic activities were decreased in the order of 3,4dimethoxy benzylidenes $\mathbf{8 k}>4$-methoxy benzylidenes $\mathbf{8 g}>2,4$ dihydroxy benzylidenes $8 \mathbf{l}>$ 4-chloro benzylidenes $\mathbf{8 h}>4$ hydroxy benzylidenes $\mathbf{8 i}>2$,4-dichloro benzylidenes $\mathbf{8 j}$.

Then, the impact of the ring $\mathrm{C}$ was investigated. The decreased $\mathrm{IC}_{50}$ values of compounds $\mathbf{4 c}, \mathbf{4 d}, \mathbf{4 e}$, and $\mathbf{4 f}$ incorporated 1-ethyl-4methylbenzene as ring $\mathrm{C}$, than those of their corresponding members $\mathbf{4 h}, \mathbf{4} \mathbf{i}, \mathbf{4 j}$, and $\mathbf{4 k}$ incorporating 1-ethyl-4-methoxybenzene as ring $\mathrm{C}$, indicated that 1-ethyl-4-methylbenzene moiety is advantageous. Also, the decreased $\mathrm{IC}_{50}$ value of compound $\mathbf{5 a}$ incorporating 1-ethyl-4-methylbenzene as ring $\mathrm{C}$ than the corresponding member 5b 1-ethyl-4-methoxybenzene as ring $\mathrm{C}$, confirm the positive effect of 1-ethyl-4-methylbenzene moiety. In addition, the higher activity of compound 9a incorporated 2-ethylthiophene moiety as ring $\mathrm{C}$ than compounds $\mathbf{9 b}$ with 2-ethylfuran moiety, revealed that 2-ethylthiophene moiety is more preferred biologically than 2-ethylfuran one.

\section{Conclusion}

To sum up, thirty-one new derivatives based on thiazol-5(4H)one were designed and eco-friendly synthesized using conventional, ultrasound irradiation and microwave-assisted methods. The synthesized derivatives were evaluated for their anti-proliferative activities against a group of three human cancer cell lines including; colorectal carcinoma (HCT-116), hepatocellular carcinoma (HepG-2), and breast cancer (MCF-7) using MTT assay. Compound $4 \mathbf{f}$ has appeared as the most active member against all examined cells with $\mathrm{IC}_{50}$ values of $5.66 \pm 0.1,2.89 \pm 0.1$, and $4.46 \pm 0.1 \mu \mathrm{M}$, respectively, as it was 1.64, 2.57 and 2.34 times more active than colchicine $\left(\mathrm{IC}_{50}=\right.$ $9.30 \pm 0.2,7.44 \pm 0.2$, and $10.45 \pm 0.3 \mu \mathrm{M}$, respectively). In addition, compounds 5a, 8f, $\mathbf{8 g}$ and $\mathbf{8 k}$ showed excellent antiproliferative activity against the three tested cell lines with $\mathrm{IC}_{50}$ values ranging from 3.23 to $9.29 \mu \mathrm{M}$. Moreover, the most active compounds have been studied for their inhibitory activities of tubulin polymerization. Tubulin polymerization assay findings were consistent with cytotoxicity data results. Moreover, compound 5a arrested the cell cycle in the G2/M phase and induced apoptosis in HepG-2 cells. Docking experiments assisted these findings by anticipating potential binding interactions between the target compounds and the active sites of tubulin heterodimers. The most effective candidates in the quest for strong and selective antineoplastic agents will serve as valuable lead compounds and merit further investigations.

\section{Experimental}

\subsection{Chemistry}

All melting points were measured on a Gallen Kamp melting point apparatus (Sanyo Gallen Kamp, UK) and were uncorrected. The Microwave reactions were done by Microsynth instrument type MA143 (Micro wave flux). The ultrasoundassisted reactions were performed in Digital Ultrasonic Cleaner CD-4830 $(35 \mathrm{KHz}, 310 \mathrm{~W})$. The IR spectra were recorded on a Pye-Unicam SP-3-300 infrared spectrophotometer $(\mathrm{KBr}$ dicks) and expressed in wave number $\left(\mathrm{cm}^{-1}\right) .{ }^{1} \mathrm{H}$ NMR spectra were run at 300 and $400 \mathrm{MHz}$, on a Varian Mercury VX-300 and Bruker Avance III NMR spectrometer, respectively, while ${ }^{13} \mathrm{C}$ NMR spectra were run at $100 \mathrm{MHz}$. TMS was used as an internal standard in deuterated dimethylsulphoxide (DMSO- $\left.d_{6}\right)$. The mass spectra were recorded on Shimadzu GCMS-QP-1000EX mass spectrometer at $70 \mathrm{eV}$. Elemental analyses were performed on CHN analyzer and all compounds were within \pm 0.4 of the theoretical values. The reactions were monitored by thinlayer chromatography (TLC) using TLC sheets coated with UV fluorescent silica gel Merck 60 F254 plates and were visualized using UV lamp and different solvents as mobile phases. All reagents and solvents were purified and dried by standard techniques.

4.1.1. General procedure for synthesis of compounds $3 a, b$ \& 7a,b. A solution of thiosemicarbazide $(10 \mathrm{mmol})$ and aryl ketones $(10 \mathrm{mmol})$ namely, 4-methyl acetophenone 1a, 3,4methoxy acetophenone 1b, 2-acetyl thiophene $\mathbf{6 a}$ and 2-acetyl furan $\mathbf{6 b}$, in anhydrous ethanol $(20 \mathrm{~mL})$ and few drops of $\mathrm{g}$. acetic acid was refluxed for $2 \mathrm{~h}$. The formed product was filtered, washed with ethanol, dried and crystallized from ethanol to give compounds $\mathbf{3 a}, \mathbf{b} \& \mathbf{7} \mathbf{a}, \mathbf{b}$, respectively. 
4.1.1.1. (E)-2-(1-(p-Tolyl)ethylidene)hydrazine-1-carbothioamide (3a). White crystals; mp 240-242 ${ }^{\circ} \mathrm{C}$; IR $\left(\mathrm{KBr}, \mathrm{cm}^{-1}\right)$ : 3376, 3230, $3151\left(\mathrm{NH}_{2}, \mathrm{NH}\right), 3053$ ( $\mathrm{CH}$ aromatic), 2933 (CH aliphatic), 1590 $(\mathrm{C}=\mathrm{N}) ;{ }^{1} \mathrm{H}$ NMR (DMSO- $\left.d_{6}\right) \delta$ ppm: $2.32\left(\mathrm{~s}, 3 \mathrm{H}, \mathrm{CH}_{3}\right), 2.41(\mathrm{~s}, 3 \mathrm{H}$, $\mathrm{CH}_{3}$ ), $7.16\left(\mathrm{~d}, 2 \mathrm{H}, J=6.6 \mathrm{~Hz}, \mathrm{Ar}-\mathrm{H}, \mathrm{H}_{3}, \mathrm{H}_{5}\right.$ of phenyl), $7.44(\mathrm{~d}, 2 \mathrm{H}, J$ $=6.6 \mathrm{~Hz}, \mathrm{Ar}-\mathrm{H}, \mathrm{H}_{2}, \mathrm{H}_{6}$ of phenyl), $8.20\left(\mathrm{~s}, 2 \mathrm{H}, \mathrm{NH}_{2}, \mathrm{D}_{2} \mathrm{O}\right.$ exchangeable), 10.12 (s, 1H, NH, $\mathrm{D}_{2} \mathrm{O}$ exchangeable); anal. calcd for $\mathrm{C}_{10} \mathrm{H}_{13} \mathrm{~N}_{3} \mathrm{~S}$ (207.3): C, 57.94; H, 6.32; N, 20.27; found: C, 57.73; H, 6.22; N, 20.15\%.

4.1.1.2. (E)-2-(1-(3,4-Dimethoxyphenyl)ethylidene)hydrazine1-carbothioamide (3b). White crystals (yield 85\%); mp 205$207^{\circ} \mathrm{C}^{\circ} \mathrm{C}$; IR $\left(\mathrm{KBr}, \mathrm{cm}^{-1}\right): 3375,3267,3157\left(\mathrm{NH}_{2}, \mathrm{NH}\right), 3099(\mathrm{CH}$ aromatic), 2931 ( $\mathrm{CH}$ aliphatic), $1599(\mathrm{C}=\mathrm{N}), 1245(\mathrm{C}=\mathrm{S}) ;{ }^{1} \mathrm{H}$ NMR (DMSO- $\left.d_{6}\right) \delta$ ppm: $2.32\left(\mathrm{~s}, 3 \mathrm{H}, \mathrm{CH}_{3}\right), 3.80\left(\mathrm{~s}, 3 \mathrm{H}, \mathrm{OCH}_{3}\right)$, $6.91\left(\mathrm{~s}, 3 \mathrm{H}, \mathrm{OCH}_{3}\right), 6.97$ (d, $1 \mathrm{H}, J=8 \mathrm{~Hz}, \mathrm{Ar}-\mathrm{H}, \mathrm{H}_{5}$ of phenyl), 7.47 (d, $2 \mathrm{H}, J=8 \mathrm{~Hz}, \mathrm{Ar}-\mathrm{H}, \mathrm{H}_{2}, \mathrm{H}_{6}$ of phenyl), $8.20\left(\mathrm{~s}, 2 \mathrm{H}, \mathrm{NH}_{2}\right.$, $\mathrm{D}_{2} \mathrm{O}$ exchangeable), $10.04\left(\mathrm{~s}, 1 \mathrm{H}, \mathrm{NH}, \mathrm{D}_{2} \mathrm{O}\right.$ exchangeable $) ;{ }^{13} \mathrm{C}$ NMR (DMSO- $d_{6}$ ) $\delta$ ppm: 179.0, 150.6, 149.0, 148.7, 130.8, 120.4, 111.4, 110.0, 56.1, 55.9, 14.4; anal. calcd for $\mathrm{C}_{11} \mathrm{H}_{15} \mathrm{~N}_{3} \mathrm{O}_{2} \mathrm{~S}$ (253.3): C,52.16; H, 5.97; N, 16.59; found: C, 51.91; H, 5.88; N, $16.48 \%$.

4.1.1.3. (E)-2-(1-(Thiophen-2-yl)ethylidene)hydrazine-1carbothioamide (7a). White crystals (yield 75\%); mp 122$124{ }^{\circ} \mathrm{C}$; IR $\left(\mathrm{KBr}, \mathrm{cm}^{-1}\right): 3407,3241,3145\left(\mathrm{NH}_{2}, \mathrm{NH}\right), 2979$ (CH aliphatic), $1606(\mathrm{C}=\mathrm{N}) ;{ }^{1} \mathrm{H}$ NMR (DMSO- $\left.d_{6}\right) \delta \mathrm{ppm}$ : $2.29\left(\mathrm{~s}, 3 \mathrm{H}, \mathrm{CH}_{3}\right), 6.47\left(\mathrm{~s}, 2 \mathrm{H}, \mathrm{NH}_{2}, \mathrm{D}_{2} \mathrm{O}\right.$ exchangeable), $7.02-704(\mathrm{~m}, 1 \mathrm{H}, \mathrm{Ar}-\mathrm{H}), 7.31(\mathrm{~d}, 1 \mathrm{H}, \mathrm{Ar}-\mathrm{H}), 7.35(\mathrm{~d}, 1 \mathrm{H}$, $\mathrm{Ar}-\mathrm{H}), 8.73\left(\mathrm{~s}, 1 \mathrm{H}, \mathrm{NH}, \mathrm{D}_{2} \mathrm{O}\right.$ exchangeable); anal. calcd for $\mathrm{C}_{7} \mathrm{H}_{9} \mathrm{~N}_{3} \mathrm{~S}_{2}$ (199.0): C, 42.19; $\mathrm{H}, 4.55 ; \mathrm{N}, 21.09$; found: $\mathrm{C}$, 41.95 ; H, 4.46; N, $21.00 \%$.

4.1.1.4. (E)-2-(1-(Furan-2-yl)ethylidene)hydrazine-1-carbothioamide (7b). White crystals; mp 122-124 ${ }^{\circ} \mathrm{C}$; IR (KBr, cm $\left.{ }^{-1}\right)$ : 3346, 3249, 3132 $\left(\mathrm{NH}_{2}, \mathrm{NH}\right), 3053$ (CH aromatic), $2933\left(\mathrm{CH}\right.$ aliphatic), $1602(\mathrm{C}=\mathrm{N}) ;{ }^{1} \mathrm{H}$ NMR (DMSO- $\left.d_{6}\right) \delta$ ppm: 2.26 (s, 3H, $\left.\mathrm{CH}_{3}\right), 6.56-6.57$ (m, $\left.1 \mathrm{H}, \mathrm{Ar}-\mathrm{H}\right)$, 7.07 (d, 1H, Ar-H), 7.73 (s, 2H, $\mathrm{NH}_{2}, \mathrm{D}_{2} \mathrm{O}$ exchangeable), 8.25 (d, $1 \mathrm{H}$, $\mathrm{Ar}-\mathrm{H}), 10.35$ (s, 1H, NH, $\mathrm{D}_{2} \mathrm{O}$ exchangeable); anal. calcd for $\mathrm{C}_{7} \mathrm{H}_{9} \mathrm{~N}_{3} \mathrm{OS}$ (183.2): C, 45.89; H, $4.95 \mathrm{~N}, 22.93$; found: $\mathrm{C}, 45.76 ; \mathrm{H}$, 4.86; N, 22.80\%.

4.1.2. General procedure for synthesis of compounds $4 a-k$, $5 a, b, 8 a-1$ \& 9a,b

4.1.2.a. Conventional method. A mixture of starting compounds $3 \mathbf{a}, \mathbf{b} \& \mathbf{7} \mathbf{a}, \mathbf{b}(10 \mathrm{mmol})$, chloroacetic acid $(1 \mathrm{mmol})$, and the appropriate aromatic aldehyde $(10 \mathrm{mmol})$ namely, 4methoxy benzaldehyde, 4-chloro benzaldehyde, 4-hydroxy benzaldehyde, 2,4-dichloro benzaldehyde, 3,4-dimethoxy benzaldehyde, and 2,4-dihydroxy benzaldehyde was refluxed in a mixture of ethanol $(20 \mathrm{~mL})$ and acetic acid glacial $(5 \mathrm{~mL})$ for 3 h. After cooling, the formed precipitate were filtered and crystallized from methanol to afford the corresponding compounds $\mathbf{4 a - k , ~ 5 a , b , ~ 8 a - 1 ~ \& ~ 9 a , b , ~ r e s p e c t i v e l y . ~}$

4.1.2.b. Under microwave method. A mixture of thiosemicarbazide $(10 \mathrm{mmol})$, appropriate aryl ketones $(10 \mathrm{mmol})$ namely, 4-methyl acetophenone 1a, 3,4-methoxy acetophenone 1b, 2-acetyl thiophene $\mathbf{6 a}$ and 2-acetyl furan $\mathbf{6 b}$, and glacial acetic acid $(2 \mathrm{~mL})$ was added to the reaction vessel placed into the microwave reactor. The mixture was allowed to react under microwave irradiation of $200-400 \mathrm{~W}$ at $120{ }^{\circ} \mathrm{C}$ for $2 \mathrm{~min}$. After the reaction completion (monitored by TLC), a mixture of chloroacetic acid $(10 \mathrm{mmol})$ and appropriate aromatic aldehydes (10 mmol) namely, 4-methoxy benzaldehyde, 4-chloro benzaldehyde, 4-hydroxy benzaldehyde, 2,4-dichloro benzaldehyde, 3,4-dimethoxy benzaldehyde, and 2,4-dihydroxy benzaldehyde was added to the reaction vessel. The reaction mixture was then subjected to microwave irradiation of $200-400 \mathrm{~W}$ at $120{ }^{\circ} \mathrm{C}$ for $2 \mathrm{~min}$. with continuous stirring via the automatic mode. The reaction was monitored using TLC. After completion of the reaction and cooling, the product was obtained and crystallized from the proper solvent to give the corresponding title compounds $\mathbf{4 a - k}, \mathbf{5 a}, \mathbf{b}, \mathbf{8 a}-\mathbf{1} \& \mathbf{9 a}, \mathbf{b}$.

4.1.2.c. Under sonication method. A mixture of thiosemicarbazide $(10 \mathrm{mmol})$ and appropriate aryl ketones (10 mmol) namely, 4-methyl acetophenone 1a, 3,4-methoxy acetophenone 1b, 2-acetyl thiophene $\mathbf{6 a}$ and 2-acetyl furan $\mathbf{6 b}$, in anhydrous ethanol $(20 \mathrm{~mL})$ with catalytic amount of glacial acetic acid was placed in Erlenmyer flask $(50 \mathrm{~mL})$ and subjected to ultrasound waves at room temperature for $10 \mathrm{~min}$. A mixture of chloroacetic acid $(10 \mathrm{mmol})$ and $(1 \mathrm{mmol})$ of appropriate aromatic aldehydes namely, 4-methoxy benzaldehyde, 4-chloro benzaldehyde, 4-hydroxy benzaldehyde, 2,4-dichloro benzaldehyde, 3,4-dimethoxy benzaldehyde, and 2,4-dihydroxy benzaldehyde was added to the reaction vessel, and subjected to ultrasound waves at room temperature for $15 \mathrm{~min}$. The formed precipitate was filtered, dried, and crystallized from the appropriate solvent to afford the target compounds $\mathbf{4 a - k , ~ 5 a , b}$, 8a-1 \& 9a,b. Reaction time and yield of the conventional, ultrasonic and microwave procedures were summarized in Table 5.

4.1.2.c.1. 4-((E)-4-Methoxybenzylidene)-2-(2-((E)-1-(p-tolyl)ethylidene)hydrazinyl) thiazol-5(4H)-one (4a). Yellow crystals; $\mathrm{mp}$ 248-250 ${ }^{\circ} \mathrm{C}$; IR (KBr, cm ${ }^{-1}$ ): 3112 (NH), 3009 (CH-aromatic), 2973 (CH aliphatic), $1722(\mathrm{C}=\mathrm{O}), 1636(\mathrm{C}=\mathrm{N}) ;{ }^{1} \mathrm{H} \quad \mathrm{NMR}$ $\left(\mathrm{DMSO}-d_{6}\right) \delta$ ppm: $3.31\left(\mathrm{~s}, 6 \mathrm{H}, 2 \mathrm{CH}_{3}\right), 3.86\left(\mathrm{~s}, 3 \mathrm{H}, \mathrm{OCH}_{3}\right), 6.98-$ $7.06(\mathrm{~m}, 4 \mathrm{H}, \mathrm{Ar}-\mathrm{H}), 7.67-7.72(\mathrm{~d}, 4 \mathrm{H}, \mathrm{Ar}-\mathrm{H}), 8.31$ (s, 1H, C=C $\underline{\mathrm{H}}$ olefinic), 11.88 (s, 1H, NH, $\mathrm{D}_{2} \mathrm{O}$ exchangeable); anal. calcd for $\mathrm{C}_{20} \mathrm{H}_{19} \mathrm{~N}_{3} \mathrm{O}_{2} \mathrm{~S}$ (365.5): C, 65.73; H, 5.24; N, 11.50; found: C, 65.51; $\mathrm{H}, 5.16$; N, $11.41 \%$.

4.1.2.c.2. 4-((E)-4-Chlorobenzylidene)-2-(2-((E)-1-(p-tolyl)ethylidene)hydrazinyl) thiazol-5(4H)-one (4b). Pale yellow crystals; $\mathrm{mp}$ 266-268 ${ }^{\circ} \mathrm{C}$; IR $\left(\mathrm{KBr}, \mathrm{cm}^{-1}\right)$ : $3112(\mathrm{NH}), 3027$ (CH-aromatic), 2938 ( $\mathrm{CH}$ aliphatic), $1709(\mathrm{C}=\mathrm{O}), 1644(\mathrm{C}=\mathrm{N}) ;{ }^{1} \mathrm{H} \quad \mathrm{NMR}$ (DMSO- $\left.d_{6}\right) \delta$ ppm: $3.31\left(\mathrm{~s}, 3 \mathrm{H}, \mathrm{CH}_{3}\right), 3.88\left(\mathrm{~s}, 3 \mathrm{H}, \mathrm{CH}_{3}\right), 7.47-7.96$ $(\mathrm{m}, 4 \mathrm{H}, \mathrm{Ar}-\mathrm{H}), 7.70-7.80(\mathrm{~m}, 4 \mathrm{H}, \mathrm{Ar}-\mathrm{H}), 8.39(\mathrm{~s}, 1 \mathrm{H}, \mathrm{C}=\mathrm{CH}$ olefinic), 11.98 (s, $1 \mathrm{H}, \mathrm{NH}, \mathrm{D}_{2} \mathrm{O}$ exchangeable); anal. calcd for $\mathrm{C}_{19} \mathrm{H}_{16} \mathrm{ClN}_{3} \mathrm{OS}$ (369.9): C, 61.70; H, 4.36; N, 11.36; found: $\mathrm{C}$, $61.55 ; \mathrm{H}, 4.26$; N, 11.24\%.

4.1.2.c.3. 4-((E)-4-Hydroxybenzylidene)-2-(2-((E)-1-(p-tolyl)ethylidene)hydrazinyl) thiazol-5(4H)-one (4c). Yellow crystals; $\mathrm{mp}$ 272-274 ${ }^{\circ} \mathrm{C}$; IR (KBr, cm $\left.{ }^{-1}\right): 3420(\mathrm{OH}), 3170(\mathrm{NH}), 3035(\mathrm{CH}-$ aromatic), 2924 ( $\mathrm{CH}$ aliphatic), $3170(\mathrm{NH}), 1689(\mathrm{C}=\mathrm{O}), 1638$ $(\mathrm{C}=\mathrm{N}) ;{ }^{1} \mathrm{H}$ NMR (DMSO- $\left.d_{6}\right) \delta$ ppm: $2.49\left(\mathrm{~s}, 3 \mathrm{H}, \mathrm{CH}_{3}\right), 3.85(\mathrm{~s}$, $\left.3 \mathrm{H}, \mathrm{CH}_{3}\right), 6.82-6.86(\mathrm{~m}, 4 \mathrm{H}, \mathrm{Ar}-\mathrm{H}), 7.56-7.63(\mathrm{~m}, 4 \mathrm{H}, \mathrm{Ar}-\mathrm{H})$, $8.25\left(\mathrm{~s}, \quad 1 \mathrm{H}, \mathrm{C}=\mathrm{C} \underline{\mathrm{H}}\right.$ olefinic), $9.94\left(\mathrm{~s}, \quad 1 \mathrm{H}, \quad \mathrm{NH}, \quad \mathrm{D}_{2} \mathrm{O}\right.$ 
exchangeable), 11.83 (s, $1 \mathrm{H}, \mathrm{OH}, \mathrm{D}_{2} \mathrm{O}$ exchangeable); anal. calcd for $\mathrm{C}_{19} \mathrm{H}_{17} \mathrm{~N}_{3} \mathrm{O}_{2} \mathrm{~S}$ (351.4): C, 64.94; $\mathrm{H}, 4.88 ; \mathrm{N}, 11.96$; found: $\mathrm{C}$, $64.75 ; \mathrm{H}, 4.80 ; \mathrm{N}, 11.85 \%$.

4.1.2.c.4. 4-((E)-2,4-Dichlorobenzylidene)-2-(2-((E)-1-(p-tolyl) ethylidene)hydrazinyl) thiazol-5(4H)-one $(\mathbf{4 d})$. White crystals; $\mathrm{mp}>300{ }^{\circ} \mathrm{C}$; IR $\left(\mathrm{KBr}, \mathrm{cm}^{-1}\right): 3115(\mathrm{NH}), 3066$ (CH-aromatic), 2945 (CH aliphatic), $1720(\mathrm{C}=\mathrm{O}), 1644(\mathrm{C}=\mathrm{N}) ;{ }^{1} \mathrm{H}$ NMR $\left(\mathrm{DMSO}-d_{6}\right) \delta$ ppm: $3.30\left(\mathrm{~s}, 3 \mathrm{H}, \mathrm{CH}_{3}\right), 3.98\left(\mathrm{~s}, 3 \mathrm{H}, \mathrm{CH}_{3}\right), 7.47$ (d, $2 \mathrm{H}, \mathrm{Ar}-\mathrm{H}), 7.74$ (d, 2H, Ar-H), 7.94 (d, 2H, Ar-H, $J=8.4$ ), 8.65 (s, $1 \mathrm{H}, \mathrm{C}=\mathrm{CH}$ olefinic), $8.66(\mathrm{~s}, 1 \mathrm{H}$ of $\mathrm{Ar}-\mathrm{H}), 12.09(\mathrm{~s}, 1 \mathrm{H}, \mathrm{NH}$, $\mathrm{D}_{2} \mathrm{O}$ exchangeable); anal. calcd for $\mathrm{C}_{19} \mathrm{H}_{15} \mathrm{Cl}_{2} \mathrm{~N}_{3} \mathrm{OS}$ (404.3): C, 56.44; H, 3.74; N, 10.39; found: C, 56.28; H, 3.65; N, $10.27 \%$.

4.1.2.c.5. 4-((E)-3,4-Dimethoxybenzylidene)-2-(2-((E)-1-(ptolyl)ethylidene)hydrazinyl) thiazol-5(4H)-one (4e). Off white crystals; mp 254-256 ${ }^{\circ} \mathrm{C}$; IR $\left(\mathrm{KBr}, \mathrm{cm}^{-1}\right): 3114(\mathrm{NH}), 2949$ (CH aliphatic), $1704(\mathrm{C}=\mathrm{O}), 1648(\mathrm{C}=\mathrm{N}) ;{ }^{1} \mathrm{H}$ NMR (DMSO$\left.d_{6}\right) \delta \mathrm{ppm}: 3.32\left(\mathrm{~s}, 3 \mathrm{H}, \mathrm{CH}_{3}\right), 3.67\left(\mathrm{~s}, 3 \mathrm{H}, \mathrm{CH}_{3}\right), 3.83(\mathrm{~s}, 3 \mathrm{H}$, $\left.\mathrm{OCH}_{3}\right), 3.88\left(\mathrm{~s}, 3 \mathrm{H}, \mathrm{OCH}_{3}\right), 6.94-7.33(\mathrm{~m}, 6 \mathrm{H}, \mathrm{Ar}-\mathrm{H}), 8.27$ (s, $1 \mathrm{H}, \mathrm{C}=\mathrm{C} \underline{\mathrm{H}}$ olefinic $+\mathrm{s}, 1 \mathrm{H}$ of $\mathrm{Ar}-\mathrm{H}), 11.80\left(\mathrm{~s}, 2 \mathrm{H}, \mathrm{NH}, \mathrm{D}_{2} \mathrm{O}\right.$ exchangeable), ${ }^{13} \mathrm{C}$ NMR (DMSO- $\left.d_{6}\right) \delta$ ppm: 178.2, 161.7, 160.4, 158.3, 158.1, 157.1, 153.5, 142.6, 142.0, 139.4, 130.1, 129.2 (2), 1284 (2), 112.3, 110.2, 56.6, 56.1, 33.4, 13.7; anal. calcd for $\mathrm{C}_{21} \mathrm{H}_{21} \mathrm{~N}_{3} \mathrm{O}_{3} \mathrm{~S}$ (395.5): C, 63.78; H, 5.35; N, 10.63; found: C, 63.59; H, 5.27; N, 10.50\%.

4.1.2.c.6. 4-((E)-2,4-Dihydroxybenzylidene)-2-(2-((E)-1-(p-tolyl) ethylidene)hydrazinyl) thiazol-5(4H)-one (4f). Red crystals; $\mathrm{mp}$ over $300{ }^{\circ} \mathrm{C}$; IR (KBr, cm $\left.{ }^{-1}\right)$ : $3441(\mathrm{OH}), 3204(\mathrm{NH}), 3037\left(\mathrm{CH}^{-}\right.$ aromatic), 2935 ( $\mathrm{CH}$ aliphatic), $1697(\mathrm{C}=\mathrm{O}), 1625(\mathrm{C}=\mathrm{N}) ;{ }^{1} \mathrm{H}$ NMR (DMSO- $\left.d_{6}\right) \delta$ ppm: $2.47\left(\mathrm{~s}, 3 \mathrm{H}, \mathrm{CH}_{3}\right), 3.93\left(\mathrm{~s}, 3 \mathrm{H}, \mathrm{CH}_{3}\right)$, 6.29-6.37 (m, 4H, Ar-H), 7.33 (d, 2H, Ar-H, $J=8.4$ ), 8.47 (s, 1H, $\mathrm{C}=\mathrm{C} \underline{\mathrm{H}}$ olefinic $+\mathrm{s}, 1 \mathrm{H}$ of $\mathrm{Ar}-\mathrm{H}), 10.08(\mathrm{~s}, 1 \mathrm{H}, \mathrm{NH}$, for thiazole tautomer, $\mathrm{D}_{2} \mathrm{O}$ exchangeable), $11.02\left(\mathrm{~s}, 1 \mathrm{H}, 2 \mathrm{OH}, \mathrm{D}_{2} \mathrm{O}\right.$ exchangeable), $11.94\left(\mathrm{~s}, 1 \mathrm{H}, \mathrm{NH}\right.$, for thiazole tautomer $\mathrm{D}_{2} \mathrm{O}$ exchangeable); ${ }^{13} \mathrm{C}$ NMR (DMSO- $\left.d_{6}\right) \delta$ ppm: 174.0, 161.8 (2), $160.6,158.7(2), 133.0,132.1,110.8,110.0,109.0(2), 108.4(2)$, 102.8 (2), 102.0, 40.5, 19.7; anal. calcd for $\mathrm{C}_{19} \mathrm{H}_{17} \mathrm{~N}_{3} \mathrm{O}_{3} \mathrm{~S}(367.4)$ : C, 62.11; H, 4.66; N, 11.44; found: C, 61.89; H, 4.57; N, 11.31\%.

4.1.2.c.7. 2-(2-((E)-1-(3,4-Dimethoxyphenyl)ethylidene)hydrazinyl)-4-((E)-4-methoxy benzylidene) thiazol-5(4H)-one (4g). White crystals; mp $240-242{ }^{\circ} \mathrm{C}$; IR $\left(\mathrm{KBr}, \mathrm{cm}^{-1}\right): 3149(\mathrm{NH}), 3035(\mathrm{CH}-$ aromatic), 2964 (CH aliphatic), $1721(\mathrm{C}=\mathrm{O}), 1621(\mathrm{C}=\mathrm{N}) ;{ }^{1} \mathrm{H}$ NMR (DMSO- $\left.d_{6}\right) \delta$ ppm: $3.82\left(\mathrm{~s}, 3 \mathrm{H}, \mathrm{CH}_{3}\right), 3.84\left(\mathrm{~s}, 3 \mathrm{H}, \mathrm{OCH}_{3}\right)$, $3.85\left(\mathrm{~s}, 3 \mathrm{H}, \mathrm{OCH}_{3}\right), 3.86\left(\mathrm{~s}, 3 \mathrm{H}, \mathrm{OCH}_{3}\right), 6.96$ (d, $2 \mathrm{H}, \mathrm{Ar}-\mathrm{H}, J=8$ $\mathrm{Hz}$ ), 7.01 (s, 1H, Ar-H), 7.33 (d, 2H, Ar-H, $J=8 \mathrm{~Hz}), 7.47$ (d, 1H, $\mathrm{Ar}-\mathrm{H}, J=8 \mathrm{~Hz}$ ), $7.68(\mathrm{~d}, 1 \mathrm{H}, \mathrm{Ar}-\mathrm{H}, J=8 \mathrm{~Hz}), 8.31(\mathrm{~s}, 1 \mathrm{H}, \mathrm{C}=\mathrm{CH}$ olefinic), $11.87\left(\mathrm{~s}, 1 \mathrm{H}, \mathrm{NH}, \mathrm{D}_{2} \mathrm{O}\right.$ exchangeable); ${ }^{13} \mathrm{C} \mathrm{NMR}$ $\left(\mathrm{DMSO}-d_{6}\right) \delta$ ppm: $160.1,152.3,151.0,148.8,130.8(2), 129.7$, 123.5, 120.3(2), 114.7, 111.5(2), 111.2, 110.6, 109.6 (2), 55.9, 55.7, 55.6, 14.2; anal. calcd for $\mathrm{C}_{21} \mathrm{H}_{21} \mathrm{~N}_{3} \mathrm{O}_{4} \mathrm{~S}$ (411.5): C, 61.30; $\mathrm{H}$, 5.14 ; N, 10.21; found: C, 61.08; H, 5.04; N, 10.11\%.

4.1.2.c.8. 2-(2-((E)-1-(3,4-Dimethoxyphenyl)ethylidene)hydrazinyl)-4-((E)-4-hydroxy benzylidene)thiazol-5(4H)-one (4h). Yellow crystals; mp 290-292 ${ }^{\circ} \mathrm{C}$; IR (KBr, cm $\left.{ }^{-1}\right): 3231(\mathrm{NH}), 2924(\mathrm{CH}$ aliphatic), 1687 (CO), $1639(\mathrm{C}=\mathrm{N}) ;{ }^{1} \mathrm{H}$ NMR (DMSO- $\left.d_{6}\right) \delta$ ppm: $3.43\left(\mathrm{~s}, 3 \mathrm{H}, \mathrm{CH}_{3}\right), 3.82\left(\mathrm{~s}, 3 \mathrm{H}, \mathrm{CH}_{3}\right), 3.84\left(\mathrm{~s}, 3 \mathrm{H}, \mathrm{CH}_{3}\right), 6.81$ (d, $2 \mathrm{H}, \mathrm{Ar}-\mathrm{H}, J=8.4 \mathrm{~Hz}$ ), 6.97 (d, 2H, Ar-H, $J=8.4 \mathrm{~Hz}$ ), 7.35-7.57 $(\mathrm{m}, 3 \mathrm{H}, \mathrm{Ar}-\mathrm{H}), 8.25\left(\mathrm{~s}, 1 \mathrm{H}, \mathrm{C}=\mathrm{CH}\right.$ olefinic), $9.96\left(\mathrm{~s}, 1 \mathrm{H}, \mathrm{NH}, \mathrm{D}_{2} \mathrm{O}\right.$ exchangeable), 11.87 (s, $1 \mathrm{H}, \mathrm{OH}, \mathrm{D}_{2} \mathrm{O}$ exchangeable); anal. calcd for $\mathrm{C}_{20} \mathrm{H}_{19} \mathrm{~N}_{3} \mathrm{O}_{4} \mathrm{~S}$ (397.4): C, 60.44; $\mathrm{H}, 4.82 ; \mathrm{N}, 10.57$; found: $\mathrm{C}$, $60.24 ; \mathrm{H}, 4.73 ; \mathrm{N}, 10.46 \%$.

4.1.2.c.9. 4-((E)-2,4-Dichlorobenzylidene)-2-(2-((E)-1-(3,4dimethoxyphenyl)ethylid-ene)hydrazineyl) thiazol-5(4H)-one (4i). Off white crystals; $\mathrm{mp}>300{ }^{\circ} \mathrm{C}$; IR $\left(\mathrm{KBr}, \mathrm{cm}^{-1}\right): 3114$, (NH), 3066 (CH-aromatic), 2944 ( $\mathrm{CH}$ aliphatic), 1721 (CO), $1644(\mathrm{C}=\mathrm{N}) ;{ }^{1} \mathrm{H}$ NMR (DMSO- $\left.d_{6}\right) \delta \mathrm{ppm}: 3.78\left(\mathrm{~s}, 3 \mathrm{H}, \mathrm{CH}_{3}\right)$, $3.82\left(\mathrm{~s}, 3 \mathrm{H}, \mathrm{OCH}_{3}\right), 3.91\left(\mathrm{~s}, 3 \mathrm{H}, \mathrm{OCH}_{3}\right), 7.51-7.62(\mathrm{~m}, 3 \mathrm{H}, \mathrm{Ar}-$ $\mathrm{H}), 7.94(\mathrm{~m}, 2 \mathrm{H}, \mathrm{Ar}-\mathrm{H}, J=8.4 \mathrm{~Hz}), 8.56(\mathrm{~s}, 1 \mathrm{H}, \mathrm{C}=\mathrm{C} \underline{\mathrm{H}}$ olefinic $+1 \mathrm{H}, \mathrm{Ar}-\mathrm{H}), 12.06$ (s, 1H, NH, $\mathrm{D}_{2} \mathrm{O}$ exchangeable); anal. calcd for $\mathrm{C}_{20} \mathrm{H}_{17} \mathrm{C}_{12} \mathrm{~N}_{3} \mathrm{O}_{3} \mathrm{~S}$ (450.3): C, 53.34; H, 3.81; N, 9.33; found: C, 53.15; H, 3.72; N, 9.22\%.

4.1.2.c.10. 4-((E)-3,4-Dimethoxybenzylidene)-2-(2-((E)-1-(3,4dimethoxyphenyl)ethylid-ene)hydrazinyl)thiazol-5(4H)-one (4j). Yellow crystals; $\mathrm{mp} 232-236^{\circ} \mathrm{C}$; IR $\left(\mathrm{KBr}, \mathrm{cm}^{-1}\right): 3433$, (NH), 2944 (CH aliphatic), 1707 (CO), $1648(\mathrm{C}=\mathrm{N}) ;{ }^{1} \mathrm{H}$ NMR (DMSO- $\left.d_{6}\right)$ $\delta$ ppm: 3.61 (s, 3H, $\left.\mathrm{CH}_{3}\right), 3.74\left(\mathrm{~s}, 3 \mathrm{H}, \mathrm{OCH}_{3}\right), 3.79\left(\mathrm{~s}, 3 \mathrm{H}, \mathrm{OCH}_{3}\right)$, $3.81\left(\mathrm{~s}, 3 \mathrm{H}, \mathrm{OCH}_{3}\right), 3.86\left(\mathrm{~s}, 3 \mathrm{H}, \mathrm{OCH}_{3}\right), 6.99$ (d, $1 \mathrm{H}, \mathrm{Ar}-\mathrm{H}, J=8$ $\mathrm{Hz}$ ), 7.05-7.15 (m, 3H, Ar-H), 7.55 (s, 1H, Ar-H), 8.29 (s, 1H, C= $\mathrm{C} \underline{\mathrm{H}}$ olefinic $+1 \mathrm{H}, \mathrm{Ar}-\mathrm{H}), 11.91\left(\mathrm{~s}, 1 \mathrm{H}, \mathrm{NH}, \mathrm{D}_{2} \mathrm{O}\right.$ exchangeable); anal. calcd for $\mathrm{C}_{22} \mathrm{H}_{23} \mathrm{~N}_{3} \mathrm{O}_{5} \mathrm{~S}$ (441.5): C, 59.85; H, 5.25; N, 9.52; found: C, 59.66; H, 5.17; N, 9.60\%.

4.1.2.c.11. 4-((E)-2,4-Dihydroxybenzylidene)-2-(2-((E)-1-(3,4dimethoxyphenyl)ethylid-ene)hydrazinyl)thiazol-5(4H)-one (4k). Red crystals; $\mathrm{mp}>300{ }^{\circ} \mathrm{C}$; IR $\left(\mathrm{KBr}, \mathrm{cm}^{-1}\right): 3214,(\mathrm{NH}), 3053(\mathrm{CH}-$ aromatic), 2975 (CH aliphatic), 1697 (CO), $1633(\mathrm{C}=\mathrm{N}) ;{ }^{1} \mathrm{H}$ NMR $\left(\mathrm{DMSO}-d_{6}\right) \delta$ ppm: $3.38\left(\mathrm{~s}, 3 \mathrm{H}, \mathrm{CH}_{3}\right), 3.77\left(\mathrm{~s}, 3 \mathrm{H}, \mathrm{OCH}_{3}\right), 3.86(\mathrm{~s}$, $3 \mathrm{H}, \mathrm{OCH}_{3}$ ), 6.29-6.38 (m, 3H, Ar-H), 7.31 (d, 2H, Ar-H), 8.47 (s, $1 \mathrm{H}, \mathrm{C}=\mathrm{CH}$ olefinic $+1 \mathrm{H}, \mathrm{Ar}-\mathrm{H}), 10.08(\mathrm{~s}, 1 \mathrm{H}, \mathrm{NH}$, for thiazol tautomer, $\mathrm{D}_{2} \mathrm{O}$ exchangeable), $11.02\left(\mathrm{~s}, 2 \mathrm{H}, \quad \mathrm{OH}, \quad \mathrm{D}_{2} \mathrm{O}\right.$ exchangeable), $11.95\left(\mathrm{~s}, 1 \mathrm{H}, \mathrm{NH}\right.$, for thiazole tautomer, $\mathrm{D}_{2} \mathrm{O}$ exchangeable); anal. calcd for $\mathrm{C}_{20} \mathrm{H}_{19} \mathrm{~N}_{3} \mathrm{O}_{5} \mathrm{~S}$ (413.4): C, 58.10; $\mathrm{H}$, 4.63 ; N, 10.16; found: C, 57.26; H, 4.55; N, 10.06\%.

4.1.2.c.12. (E)-4-(Thiophen-2-ylmethylene)-2-(2-((E)-1-(p-tolyl) ethylidene)hydrazinyl) thiazol-5(4H)-one (5a). Orange crystals; $\mathrm{mp} 202-204{ }^{\circ} \mathrm{C}$; IR $\left(\mathrm{KBr}, \mathrm{cm}^{-1}\right): 3122(\mathrm{NH}), 3051$ (CH-aromatic), 2950 (CH aliphatic), $1707(\mathrm{C}=\mathrm{O}), 1634(\mathrm{C}=\mathrm{N})$; ${ }^{1} \mathrm{H}$ NMR (DMSO$\left.d_{6}\right) \delta$ ppm: $3.86\left(\mathrm{~s}, 6 \mathrm{H}, 2 \mathrm{CH}_{3}\right), 7.06(\mathrm{~d}, 2 \mathrm{H}, \mathrm{Ar}-\mathrm{H}, J=8), 7.14(\mathrm{~m}$, $1 \mathrm{H}, \mathrm{Ar}-\mathrm{H}), 7.26$ (d, 2H, Ar-H, $J=8), 7.56$ (d, 1H, Ar-H), $7.73(\mathrm{~m}$, $1 \mathrm{H}, \mathrm{Ar}-\mathrm{H}), 8.66\left(\mathrm{~s}, 1 \mathrm{H}, \mathrm{C}=\mathrm{CH}\right.$ olefinic), $11.75\left(\mathrm{~s}, 1 \mathrm{H}, \mathrm{NH}, \mathrm{D}_{2} \mathrm{O}\right.$ exchangeable); anal. calcd for $\mathrm{C}_{17} \mathrm{H}_{15} \mathrm{~N}_{3} \mathrm{OS}_{2}$ (341.4): $\mathrm{C}, 59.80 ; \mathrm{H}$, 4.43; N, 12.31; found: C, 59.69; H, 4.35; N, 12.19\%.

\subsection{2.c.13. (E)-2-(2-((E)-1-(3,4-Dimethoxyphenyl)ethylidene)} hydrazinyl)-4-(thiophen-2-ylmethylene)thiazol-5(4H)-one (5b). Pale yellow crystals; mp $208-210{ }^{\circ} \mathrm{C}$; IR ( $\left.\mathrm{KBr}, \mathrm{cm}^{-1}\right): 3411$, (NH), 3053 (CH-aromatic), 2951 (CH aliphatic), $1709(\mathrm{CO}), 1633(\mathrm{C}=\mathrm{N}) ;{ }^{1} \mathrm{H}$ NMR (DMSO- $\left.d_{6}\right) \delta$ ppm: $3.79\left(\mathrm{~s}, 3 \mathrm{H}, \mathrm{CH}_{3}\right), 3.82\left(\mathrm{~s}, 3 \mathrm{H}, \mathrm{OCH}_{3}\right)$, $3.85\left(\mathrm{~s}, 3 \mathrm{H}, \mathrm{OCH}_{3}\right), 7.13-7.18(\mathrm{~m}, 2 \mathrm{H}, \mathrm{Ar}-\mathrm{H}), 7.47-7.48(\mathrm{~d}, 1 \mathrm{H}$, $\mathrm{Ar}-\mathrm{H}), 7.67$ (d, 2H, Ar-H,J=5.2 Hz), 8.52 (s, 1H, C= $\underline{\mathrm{H}}$ olefinic $+1 \mathrm{H}, \mathrm{Ar}-\mathrm{H}), 11.90\left(\mathrm{~s}, 1 \mathrm{H}, \mathrm{NH}, \mathrm{D}_{2} \mathrm{O}\right.$ exchangeable); anal. calcd for 
$\mathrm{C}_{18} \mathrm{H}_{17} \mathrm{~N}_{3} \mathrm{O}_{3} \mathrm{~S}_{2}$ (387.5): C, 55.80; $\mathrm{H}, 4.42 ; \mathrm{N}, 10.84$; found: $\mathrm{C}$, $55.69 ; \mathrm{H}, 4.33$; N, 10.72\%.

4.1.2.c.14. 4-((E)-4-Methoxybenzylidene)-2-(2-((E)-1-(thiophen2-yl)ethylidene)hydra-zinyl)thiazol-5(4H)-one (8a). White crystals; mp 243-245 ${ }^{\circ} \mathrm{C}$; IR (KBr, cm $\left.{ }^{-1}\right)$ : 3287, 3149, (NH), $3075(\mathrm{CH}-$ aromatic), 2934 (CH aliphatic), $1709(\mathrm{C}=\mathrm{O}), 1605(\mathrm{C}=\mathrm{N}) ;{ }^{1} \mathrm{H}$ NMR (DMSO- $\left.d_{6}\right) \delta$ ppm: $3.77\left(\mathrm{~s}, 3 \mathrm{H}, \mathrm{CH}_{3}\right), 3.85\left(\mathrm{~s}, 3 \mathrm{H}, \mathrm{OCH}_{3}\right)$, 6.98-7.02 (m, 3H, Ar-H), 7.66-7.69 (m, 4H, Ar-H), 8.31 (s, 1H, $\mathrm{C}=\mathrm{CH}$ olefinic), $11.74\left(\mathrm{~s}, 1 \mathrm{H}, \mathrm{NH}, \mathrm{D}_{2} \mathrm{O}\right.$ exchangeable); anal. calcd for $\mathrm{C}_{17} \mathrm{H}_{15} \mathrm{~N}_{3} \mathrm{O}_{2} \mathrm{~S}_{2}$ (357.4): C, 57.12; H, 4.23; N, 11.76; found: C, 56.90; H, 4.16; N, 11.64\%.

4.1.2.c.15. 4-((E)-4-Chlorobenzylidene)-2-(2-((E)-1-(thiophen-2yl)ethylidene)hydra-zinyl)thiazol-5(4H)-one (8b). Orange crystals; $\mathrm{mp} 252-254{ }^{\circ} \mathrm{C}$; IR (KBr, $\mathrm{cm}^{-1}$ ): $3145(\mathrm{NH}), 3043$ (CH-aromatic), 2936 (CH aliphatic), $1714(\mathrm{C}=\mathrm{O}), 1640(\mathrm{C}=\mathrm{N}) ;{ }^{1} \mathrm{H}$ NMR (DMSO$\left.d_{6}\right) \delta$ ppm: 3.93 (s, 3H, $\left.\mathrm{CH}_{3}\right), 7.56-7.70(\mathrm{~m}, 3 \mathrm{H}, \mathrm{Ar}-\mathrm{H}), 7.83-8.28$ $(\mathrm{m}, 3 \mathrm{H}, \mathrm{Ar}-\mathrm{H}), 8.94(\mathrm{~s}, 1 \mathrm{H}, \mathrm{C}=\mathrm{CH}$ olefinic $\mathrm{H}), 9.02(\mathrm{dd}, 1 \mathrm{H}, \mathrm{Ar}-$ $\mathrm{H}), 12.03$ (s, $1 \mathrm{H}, \mathrm{NH}, \mathrm{D}_{2} \mathrm{O}$ exchangeable); ${ }^{13} \mathrm{C}$ NMR (DMSO- $d_{6}$ ) $\delta$ ppm: 163.2, 153.2, 139.2, 138.3, 138.1, 137.4, 137.2, 136.4, 135.3, 130.1(2), 129.1(2), 121.2, 120.9, 14.1; anal. calcd for $\mathrm{C}_{16^{-}}$ $\mathrm{H}_{12} \mathrm{ClN}_{3} \mathrm{OS}_{2}$ (361.9): C, 53.11; H, 3.34; N, 11.61; found: C, 52.99; $\mathrm{H}, 3.26$; N, $11.50 \%$.

4.1.2.c.16. 4-((E)-4-Hydroxybenzylidene)-2-(2-((E)-1-(thiophen2-yl)ethylidene)hydra-zinyl)thiazol-5(4H)-one (8c). Orange crystals; mp 178-180 ${ }^{\circ} \mathrm{C}$; IR (KBr, cm $\left.{ }^{-1}\right): 3235(\mathrm{OH}), 3181(\mathrm{NH}), 3035$ (CH-aromatic), 2964 (CH aliphatic), $1688(\mathrm{C}=\mathrm{O}), 1641(\mathrm{C}=\mathrm{N})$; ${ }^{1} \mathrm{H}$ NMR (DMSO- $\left.d_{6}\right) \delta$ ppm: $3.84\left(\mathrm{~s}, 3 \mathrm{H}, \mathrm{CH}_{3}\right), 6.80-6.82(\mathrm{~m}, 4 \mathrm{H}$, $\mathrm{Ar}-\mathrm{H}), 7.55-7.57$ (m, 3H, Ar-H), 8.24 (s, 1H, C= $\mathrm{CH}$ olefinic), $9.96\left(\mathrm{~s}, 1 \mathrm{H}, \mathrm{NH}, \mathrm{D}_{2} \mathrm{O}\right.$ exchangeable), $11.82\left(\mathrm{~s}, 1 \mathrm{H}, \mathrm{OH}, \mathrm{D}_{2} \mathrm{O}\right.$ exchangeable); anal. calcd for $\mathrm{C}_{16} \mathrm{H}_{13} \mathrm{~N}_{3} \mathrm{O}_{2} \mathrm{~S}_{2}$ (343.4): C, 55.96; $\mathrm{H}$, 3.82; N, 12.24; found: C, 55.79; H, 3.75; N, 12.11\%.

4.1.2.c.17. 4-((E)-2,4-Dichlorobenzylidene)-2-(2-((E)-1-(thiophen-2yl)ethylidene) hydrazinyl)thiazol-5(4H)-one (8d). Pale yellow crystals; $\mathrm{mp} 274-276{ }^{\circ} \mathrm{C}$; IR (KBr, $\left.\mathrm{cm}^{-1}\right): 3115(\mathrm{NH}), 3066$ (CH-aromatic), 2946 (CH aliphatic), $1720(\mathrm{C}=\mathrm{O}), 1643(\mathrm{C}=\mathrm{N})$; ${ }^{1} \mathrm{H}$ NMR (DMSO$\left.d_{6}\right) \delta$ ppm: $3.90\left(\mathrm{~s}, 3 \mathrm{H}, \mathrm{CH}_{3}\right), 7.51-7.53(\mathrm{dd}, 2 \mathrm{H}, \mathrm{Ar}-\mathrm{H}, J=8.4 \mathrm{~Hz})$, 7.71-7.72 (m, 2H, Ar-H), 7.93-7.95 (m, 2H, Ar-H), 8.56 (s, 1H, C= CH olefinic), 12.08 (s, 1H, NH, $\mathrm{D}_{2} \mathrm{O}$ exchangeable); anal. calcd for $\mathrm{C}_{16} \mathrm{H}_{11} \mathrm{C}_{12} \mathrm{~N}_{3} \mathrm{OS}_{2}$ (396.3): C, 48.49; $\mathrm{H}, 2.80 ; \mathrm{N}, 10.60$; found: $\mathrm{C}, 48.34$; $\mathrm{H}, 2.71 ; \mathrm{N}, 10.50 \%$.

4.1.2.c.18. 4-((E)-3,4-Dimethoxybenzylidene)-2-(2-((E)-1-(thiophen2-yl)ethylidene) hydrazinyl) thiazol-5(4H)-one (8e). Buff crystals; $\mathrm{mp}$ 248-250 ${ }^{\circ} \mathrm{C}$; IR (KBr, cm ${ }^{-1}$ ): 3122, (NH), 3056 (CH-aromatic), 2943 (CH aliphatic), $1703(\mathrm{C}=\mathrm{O}), 1648(\mathrm{C}=\mathrm{N}) ;{ }^{1} \mathrm{H}$ NMR (DMSO- $\left.d_{6}\right)$ $\delta$ ppm: 3.75 (s, 3H, $\left.\mathrm{CH}_{3}\right), 3.84\left(\mathrm{~s}, 6 \mathrm{H}, \mathrm{OCH}_{3}\right), 6.97$ (d, 2H, $\mathrm{Ar}-\mathrm{H}, J=8$ $\mathrm{Hz}$ ), 7.07 (s, 1H, Ar-H), 7.14 (d, 2H, Ar-H), 7.53-7.54 (m, 1H, Ar-H), $8.40\left(\mathrm{~s}, 1 \mathrm{H}, \mathrm{C}=\mathrm{CH}\right.$ olefinic), $12.56\left(\mathrm{~s}, 1 \mathrm{H}, \mathrm{NH}, \mathrm{D}_{2} \mathrm{O}\right.$ exchangeable); anal. calcd for $\mathrm{C}_{18} \mathrm{H}_{17} \mathrm{~N}_{3} \mathrm{O}_{3} \mathrm{~S}_{2}$ (387.5): C, 55.80; H, 4.42; N, 10.84; found: C, 55.66; H, 4.31; N, 10.77\%.

4.1.2.c.19. 4-((E)-2,4-Dihydroxybenzylidene)-2-(2-((E)-1-(thiophen2-yl)ethylidene) hydrazinyl) thiazol-5(4H)-one (8f). Red crystals; $\mathrm{mp}>$ $300{ }^{\circ} \mathrm{C}$; IR (KBr, cm ${ }^{-1}$ ): 3208 (OH, NH), 3092 (CH-aromatic), 2975 (CH aliphatic), $1697(\mathrm{C}=\mathrm{O}), 1625(\mathrm{C}=\mathrm{N}) ;{ }^{1} \mathrm{H}$ NMR (DMSO- $\left.d_{6}\right)$ $\delta$ ppm: 3.92 (s, 3H, $\mathrm{CH}_{3}$ ), 6.29-6.34 (m, 1H, Ar-H), 6.34-6.36 (dd, 2H,
$\mathrm{Ar}-\mathrm{H}, J=8.4 \mathrm{~Hz}), 7.21-7.33(\mathrm{~d}, 2 \mathrm{H}, \mathrm{Ar}-\mathrm{H}), 8.40(\mathrm{~s}, 1 \mathrm{H}, \mathrm{C}=\mathrm{CH}$ olefinic $+1 \mathrm{H}, \mathrm{Ar}-\mathrm{H}), 10.07\left(\mathrm{~s}, 1 \mathrm{H}, \mathrm{NH}\right.$, for thiazole tautomer $\mathrm{D}_{2} \mathrm{O}$ exchangeable), 11.02 (s, 2H, OH, $\mathrm{D}_{2} \mathrm{O}$ exchangeable), $11.94(\mathrm{~s}, 1 \mathrm{H}$, $\mathrm{NH}$, for thiazole tautomer, $\mathrm{D}_{2} \mathrm{O}$ exchangeable); anal. calcd for $\mathrm{C}_{16} \mathrm{H}_{13} \mathrm{~N}_{3} \mathrm{O}_{3} \mathrm{~S}_{2}$ (359.4): C, 53.47; H, 3.65; N, 11.69; found: C, 53.25; H, 3.53 ; N, $11.58 \%$.

4.1.2.c.20. 2-(2-((E)-1-(Furan-2-yl)ethylidene)hydrazinyl)-4-((E)4-methoxybenzylid-ene)thiazol-5(4H)-one (8g). Yellow crystals; mp 288-290 ${ }^{\circ} \mathrm{C}$; IR (KBr, cm ${ }^{-1}$ ): $3434(\mathrm{NH}), 2972$ (CH aliphatic), 1722 $(\mathrm{C}=\mathrm{O}), 1634(\mathrm{C}=\mathrm{N}), 1602(\mathrm{C}=\mathrm{C}) ;{ }^{1} \mathrm{H}$ NMR $\left(\mathrm{DMSO}-d_{6}\right) \delta \mathrm{ppm}$ : $3.83\left(\mathrm{~s}, 3 \mathrm{H}, \mathrm{CH}_{3}\right), 3.85$ (s, 3H, $\left.\mathrm{OCH}_{3}\right), 6.98-7.01$ (m, 3H, Ar-H), 7.66-7.69 (m, 4H, Ar-H), 8.31 (s, 1H, C= $\underline{\mathrm{H}}$ olefinic), 11.88 (s, $1 \mathrm{H}, \mathrm{NH}, \mathrm{D}_{2} \mathrm{O}$ exchangeable); anal. calcd for $\mathrm{C}_{17} \mathrm{H}_{15} \mathrm{~N}_{3} \mathrm{O}_{3} \mathrm{~S}$ (341.4): C, 59.81; H, 4.43; N, 12.31; found: C, 59.69; H, 4.34; N, 12.20\%.

4.1.2.c.21. 4-((E)-4-Chlorobenzylidene)-2-(2-((E)-1-(furan-2-yl) ethylidene)hydra-zinyl)thiazol-5(4H)-one (8h). Grye crystals; $\mathrm{mp}$ 272-274 ${ }^{\circ} \mathrm{C}$; IR (KBr, cm ${ }^{-1}$ ): 3199 (NH), 3027 (CH-aromatic), 2938 (CH aliphatic), $1710(\mathrm{C}=\mathrm{O}), 1643(\mathrm{C}=\mathrm{N}) ;{ }^{1} \mathrm{H} \quad \mathrm{NMR}$ (DMSO- $\left.d_{6}\right) \delta$ ppm: 3.87 (s, 3H, $\left.\mathrm{CH}_{3}\right), 7.49-7.52(\mathrm{~m}, 4 \mathrm{H}, \mathrm{Ar}-\mathrm{H})$, 7.73-7.80 (m, 3H, Ar-H), 8.39 (s, $1 \mathrm{H}, \mathrm{C}=\mathrm{C} \underline{\mathrm{H}}$ olefinic), 11.97 (s, $1 \mathrm{H}, \mathrm{NH}, \mathrm{D}_{2} \mathrm{O}$ exchangeable); ${ }^{13} \mathrm{C}$ NMR (DMSO- $d_{6}$ ) $\delta$ ppm: 162.1, 155.5 , 143.1, 142.2, 139.1, 138.0, 136.0, 133.7, 129.6, 129.4, 128.2, 127.4 (2), 111.4, 110.0, 11.3; anal. calcd for $\mathrm{C}_{16} \mathrm{H}_{12} \mathrm{ClN}_{3}$ $\mathrm{O}_{2} \mathrm{~S}$ (345.8): C, 55.57; H, 3.50; N, 12.15; found: C, 55.35; H, $3.41 ; \mathrm{N}, 12.04 \%$.

4.1.2.c.22. 2-(2-((E)-1-(Furan-2-yl)ethylidene)hydrazinyl)-4-((E)4-hydroxybenzylid-ene)thiazol-5(4H)-one (8i). Green crystals; mp 293-295 ${ }^{\circ} \mathrm{C}$; IR (KBr, cm $\left.{ }^{-1}\right): 3238(\mathrm{OH}), 3155(\mathrm{NH}), 3033\left(\mathrm{CH}^{-}\right.$ aromatic), 2922 (CH aliphatic), $1689(\mathrm{C}=\mathrm{O}), 1639(\mathrm{C}=\mathrm{N}) ;{ }^{1} \mathrm{H}$ NMR (DMSO- $\left.d_{6}\right) \delta$ ppm: $3.81\left(\mathrm{~s}, 3 \mathrm{H}, \mathrm{CH}_{3}\right), 6.76-6.82(\mathrm{~m}, 4 \mathrm{H}, \mathrm{Ar}-$ $\mathrm{H})$, 7.55-7.57 (m, 1H, Ar-H), 7.58-7.60 (d, 2H, Ar-H, $J=8 \mathrm{~Hz}$ ), $8.25\left(\mathrm{~s}, 1 \mathrm{H}, \mathrm{C}=\mathrm{CH}\right.$ olefinic), $9.96\left(\mathrm{~s}, 1 \mathrm{H}, \mathrm{NH}, \mathrm{D}_{2} \mathrm{O}\right.$ exchangeable), 11.82 (s, $1 \mathrm{H}, \mathrm{OH}, \mathrm{D}_{2} \mathrm{O}$ exchangeable); ${ }^{13} \mathrm{C}$ NMR (DMSO- $\left.d_{6}\right) \delta$ ppm: 160.3 , 159.0, 156.8, 151.3, 153.4, 153.1, 149.1, 148.5, 134.3, 129.7(2), 125.5(2), 116.2, 115.6, 11.4; anal. calcd for $\mathrm{C}_{16} \mathrm{H}_{13} \mathrm{~N}_{3} \mathrm{O}_{3} \mathrm{~S}$ (327.4): C, 58.71; H, 4.00; N, 12.84; Found: C, 58.56; H, 3.88; N, $12.71 \%$.

4.1.2.c.23. 4-((E)-2,4-Dichlorobenzylidene)-2-(2-((E)-1-(furan2-yl)ethylidene) hydrazinyl) thiazol-5(4H)-one (8j). White crystals; mp 264-266 ${ }^{\circ} \mathrm{C}$; IR ( $\left.\mathrm{KBr}, \mathrm{cm}^{-1}\right): 3159$ (NH), 3066 (CH-aromatic), 2936 (CH aliphatic), $1720(\mathrm{C}=\mathrm{O}), 1644(\mathrm{C}=\mathrm{N})$; ${ }^{1} \mathrm{H}$ NMR (DMSO$\left.d_{6}\right) \delta$ ppm: $3.91\left(\mathrm{~s}, 3 \mathrm{H}, \mathrm{CH}_{3}\right), 7.51-7.53(\mathrm{dd}, 2 \mathrm{H}, \mathrm{Ar}-\mathrm{H}, J=8.4$ $\mathrm{Hz})$, $7.72(\mathrm{~d}, 1 \mathrm{H}, \mathrm{Ar}-\mathrm{H}), 7.93-7.95(\mathrm{~m}, 2 \mathrm{H}, \mathrm{Ar}-\mathrm{H}), 8.56$ (s, 1H, C= $\mathrm{CH}$ olefinic $+1 \mathrm{H}, \mathrm{Ar}-\mathrm{H}), 12.08\left(\mathrm{~s}, 1 \mathrm{H}, \mathrm{NH}, \mathrm{D}_{2} \mathrm{O}\right.$ exchangeable); anal. calcd for $\mathrm{C}_{16} \mathrm{H}_{11} \mathrm{C}_{12} \mathrm{~N}_{3} \mathrm{O}_{2} \mathrm{~S}(380.2)$ : C, 50.54; H, 2.92; N, 11.05; found: C, 50.36; H, 2.81; N, 10.94\%.

4.1.2.c.24. 4-((E)-3,4-Dimethoxybenzylidene)-2-(2-((E)-1-(furan2-yl)ethylidene)hydra-zinyl)thiazol-5(4H)-one (8k). White crystals; mp 240-242 ${ }^{\circ} \mathrm{C}$; IR ( $\mathrm{KBr}, \mathrm{cm}^{-1}$ ): 3441 (NH), 3088 (CH-aromatic), 2919 (CH aliphatic), $1706(\mathrm{C}=\mathrm{O}), 1648(\mathrm{C}=\mathrm{N}) ;{ }^{1} \mathrm{H} \quad \mathrm{NMR}$ $\left(\mathrm{DMSO}-d_{6}\right) \delta$ ppm: $3.74\left(\mathrm{~s}, 3 \mathrm{H}, \mathrm{CH}_{3}\right), 3.82\left(\mathrm{~s}, 3 \mathrm{H}, \mathrm{OCH}_{3}\right), 3.83(\mathrm{~s}$, $\left.3 \mathrm{H}, \mathrm{OCH}_{3}\right), 7.07$ (d, 2H, Ar-H, $\left.=8.4 \mathrm{~Hz}\right), 7.27(\mathrm{~m}, 3 \mathrm{H}, \mathrm{Ar}-\mathrm{H}), 7.51$ (m, $1 \mathrm{H}, \mathrm{Ar}-\mathrm{H}), 8.29\left(\mathrm{~s}, 1 \mathrm{H}, \mathrm{C}=\mathrm{C} \underline{\mathrm{H}}\right.$ olefinic), $11.91\left(\mathrm{~s}, 1 \mathrm{H}, \mathrm{NH}, \mathrm{D}_{2} \mathrm{O}\right.$ 
exchangeable); anal. calcd for $\mathrm{C}_{18} \mathrm{H}_{17} \mathrm{~N}_{3} \mathrm{O}_{4} \mathrm{~S}$ (371.4): C, 58.21; $\mathrm{H}$, 4.61 ; N, 11.31; found: C, 58.00; H, 4.50; N, 11.40\%.

4.1.2.c.25. 4-((E)-2,4-Dihydroxybenzylidene)-2-(2-((E)-1-(furan2-yl)ethylidene) hydrazinyl) thiazol-5(4H)-one (8l). Gray crystals; $\mathrm{mp} 282-284{ }^{\circ} \mathrm{C}$; IR $\left(\mathrm{KBr}, \mathrm{cm}^{-1}\right): 3411(\mathrm{OH}), 3150(\mathrm{NH}), 3055(\mathrm{CH}-$ aromatic), 2952 (CH aliphatic), $1708(\mathrm{C}=\mathrm{O}), 1632(\mathrm{C}=\mathrm{N}) ;{ }^{1} \mathrm{H}$ NMR (DMSO- $\left.d_{6}\right) \delta$ ppm: $3.92\left(\mathrm{~s}, 3 \mathrm{H}, \mathrm{CH}_{3}\right), 6.29-6.34(\mathrm{~m}, 1 \mathrm{H}, \mathrm{Ar}-$ $\mathrm{H}), 6.34-6.36$ (d, 2H, Ar-H, $J=8.4 \mathrm{~Hz}), 7.31-7.37$ (m, 2H, Ar-H), $8.47(\mathrm{~s}, 1 \mathrm{H}, \mathrm{C}=\mathrm{CH}$ olefinic $+1 \mathrm{H}, \mathrm{Ar}-\mathrm{H}), 10.07(\mathrm{~s}, 1 \mathrm{H}, \mathrm{NH}$, for thiazole tautomer, $\mathrm{D}_{2} \mathrm{O}$ exchangeable), $11.02\left(\mathrm{~s}, 1 \mathrm{H}, 2 \mathrm{OH}, \mathrm{D}_{2} \mathrm{O}\right.$ exchangeable), $11.94\left(\mathrm{~s}, 1 \mathrm{H}, \mathrm{NH}, \mathrm{D}_{2} \mathrm{O}\right.$ exchangeable, for thiazole tautomer); anal. calcd for $\mathrm{C}_{16} \mathrm{H}_{13} \mathrm{~N}_{3} \mathrm{O}_{4} \mathrm{~S}$ (343.4): C, 55.97; $\mathrm{H}$, 3.82; N, 12.24; found: C, 55.77; H, 3.73; N, 12.14\%.

4.1.2.c.26. (E)-2-(2-((E)-1-(Thiophen-2-yl)ethylidene)hydrazinyl)-4(thiophen-2-ylmethylene)thiazol-5(4H)-one (9a). Orang crystals; $\mathrm{mp}$ 214-216 ${ }^{\circ} \mathrm{C}$; IR $\left(\mathrm{KBr}, \mathrm{cm}^{-1}\right): 3425(\mathrm{NH}), 1717(\mathrm{C}=\mathrm{O}), 1635(\mathrm{C}=\mathrm{N})$; ${ }^{1} \mathrm{H}$ NMR (DMSO- $d_{6}$ ) $\delta$ ppm: 3.93 (s, 3H, $\mathrm{CH}_{3}$ ), 7.56-7.65 (m, 3H, Ar$\mathrm{H})$, 7.94-8.08 (dd, $2 \mathrm{H}, \mathrm{Ar}-\mathrm{H}), 8.95$ (s, $1 \mathrm{H}, \mathrm{C}=\mathrm{CH}$ olefinic $\mathrm{H}$ ), 9.03 (dd, $1 \mathrm{H}, \mathrm{Ar}-\mathrm{H}$ ), 12.03 (s, 1H, NH, $\mathrm{D}_{2} \mathrm{O}$ exchangeable); anal. calcd for $\mathrm{C}_{14} \mathrm{H}_{11} \mathrm{~N}_{3} \mathrm{OS}_{3}$ (333.4): C, 50.43; H, 3.33; N, 12.60; found: C, 50.23; H, $3.40 ; \mathrm{N}, 12.51 \%$.

4.1.2.c.27. (E)-2-(2-((E)-1-(Furan-2-yl)ethylidene)hydrazinyl)-4(thiophen-2-ylmethylene) thiazol-5(4H)-one (9b). Yellow crystals; mp 203-205 ${ }^{\circ} \mathrm{C}$; IR ( $\left.\mathrm{KBr}, \mathrm{cm}^{-1}\right): 3216(\mathrm{NH}), 3091$ (CH-aromatic), 2937 (CH aliphatic), $1696(\mathrm{C}=\mathrm{O}), 1622(\mathrm{C}=\mathrm{N})$; ${ }^{1} \mathrm{H}$ NMR (DMSO$\left.d_{6}\right) \delta$ ppm: $3.85\left(\mathrm{~s}, 3 \mathrm{H}, \mathrm{CH}_{3}\right), 7.12-7.14(\mathrm{~m}, 2 \mathrm{H}, \mathrm{Ar}-\mathrm{H}), 7.47-7.48$ (d, 2H, Ar-H), 7.66-7.67 (d, 2H, Ar-H), $8.53(\mathrm{~s}, 1 \mathrm{H}, \mathrm{C}=\mathrm{C} \underline{\mathrm{H}}$ olefinic), 11.90 (s, 1H, NH, $\mathrm{D}_{2} \mathrm{O}$ exchangeable); anal. calcd for $\mathrm{C}_{14} \mathrm{H}_{11} \mathrm{~N}_{3} \mathrm{O}_{2} \mathrm{~S}_{2}$ (317.4): C, 52.98; $\mathrm{H}, 3.49 ; \mathrm{N}, 13.24$; found: $\mathrm{C}$, 52.77; H, 3.37; N, 13.13\%.

\subsection{Biological evaluation}

4.2.1. In vitro cytotoxic activity. Evalation of cytotoxic activity of the synthesized compounds was carried out using MTT assay protocol ${ }^{49,50,57}$ against a group of cancer cell lines namely; colorectal carcinoma (HCT-116), Hepatocellular carcinoma (HepG-2) and breast cancer (MCF-7) and colchicine was used as a standard drug. The cells were obtained from ATCC (American Type Culture Collection) via the Holding company for biological products and vaccines (VACSERA) (Cairo, Egypt). The anti-cancer activity was measured quantitatively as follows:

Into a medium of RPMI-1640 with $10 \%$ fetal bovine serum, the cell lines were cultured. Then, penicillin (100 units per $\mathrm{mL}$ ) and streptomycin $\left(100 \mu \mathrm{g} \mathrm{mL} \mathrm{m}^{-1}\right)$ were added at $37{ }^{\circ} \mathrm{C}$ in a $5 \%$ $\mathrm{CO}_{2}$ incubator. Next, seeding the cell lines in a 96-well plate was achieved by a density of $1.0 \times 10^{4}$ cells per well at $37^{\circ} \mathrm{C}$ for $48 \mathrm{~h}$ under $5 \% \mathrm{CO}_{2}$. After incubation period, the cell lines were treated with different concentration of the synthesized compounds and incubated for $24 \mathrm{~h}$. After treatment by $24 \mathrm{~h}, 20$ $\mu \mathrm{L}$ of MTT solution ( $5 \mathrm{mg} \mathrm{mL}{ }^{-1}$ ) was added and incubated for $4 \mathrm{~h}$. Dimethyl sulfoxide $(100 \mu \mathrm{L})$ was added into each well to dissolve the formed purple formazan. The colorimetric assay was measured and recorded at absorbance of $570 \mathrm{~nm}$ using a plate reader (EXL 800, USA). The relative cell viability in percentage was calculated as (A570 of treated samples/A570 of untreated sample) X 100. Results for $\mathrm{IC}_{50}$ values of the active compounds were summarized in Table 1.

4.2.2. In vitro tubulin polymerization assay. The effect of the synthesized compounds on tubulin polymerization was assessed turbidimetrically using a fluorescent plate reader method. ${ }^{52}$ At first, the synthesized compounds and reference drug (colchicine) were incubated in mixture of purified bovine tubulin $(10 \mu \mathrm{M})$ and buffer system containing $20 \%$ glycerol and $1 \mathrm{mM}$ ATP at $37^{\circ} \mathrm{C}$. Then, the mixture cooled to $0{ }^{\circ} \mathrm{C}$. The $\mathrm{IC}_{50}$ value was defined as the compound concentration that inhibited the extent of tubulin assembly by $50 \%$.

4.2.3. Cell cycle analysis. HepG- 2 cells were seeded at density of $2 \times 10^{5}$ cells per well and incubated for $24 \mathrm{~h}$ in sixwell plates. Fetal bovine serum (FBS, 10\%) was added, after that cells were incubated at $37{ }^{\circ} \mathrm{C}$ and $5 \% \mathrm{CO}_{2}$. The medium was replaced with (DMSO $1 \% \mathrm{v} / \mathrm{v}$ ) containing the $2.5 \mu \mathrm{M}$ of compound 5a, then incubated for $48 \mathrm{~h}$, washed with cold phosphate buffered saline (PBS), fixed with $70 \%$ ethanol, rinsed with PBS then stained with the DNA fluorochrome PI, kept for $15 \mathrm{~min}$ at $37^{\circ} \mathrm{C}$. Then samples were analyzed with a FACS Caliber flow cytometer. ${ }^{53}$

4.2.4. Annexin V-FITC apoptosis assay. The effect of the most cytotoxic compound $\mathbf{5 a}$ on apoptosis induction was analyzed using Annexin V-FITC/PI apoptosis detection kit. In this test, HepG-2 cells were stained with Annexin V fluorescein isothiocyanate (FITC) and counterstained with propidium iodide (PI). Then, HepG-2 cells in a density of $2 \times 10^{5}$ per well were incubated with compound $5 \mathrm{a}$ for $48 \mathrm{~h}$. Next, the cells were trypsinized, washed with phosphate-buffered saline (PBS), and stained for $15 \mathrm{~min}$ at $37^{\circ} \mathrm{C}$ in the dark. Finally, FACS Caliber flow cytometer was used in analysis process. ${ }^{55}$

\subsection{Docking studies}

Crystallographic structure of tubulin [PDB ID: 1SA0, resolution $3.00 \AA$ ] was retrieved from Protein Data Bank (http:// www.pdb.org) and considered as a target for docking simulation. The docking analysis was performed using MOE2014 software to evaluate the free energy and binding modes of the synthesized compounds against tubulin. At first, the crystal structure of the target was prepared by removing water molecules and retaining the two essential chains and the cocrystallized ligand, $N$-deacetyl- $N$-(2-mercaptoacetyl)-colchicine (DAMA-colchicine). Then, the protein structure was protonated, and the hydrogen atoms were hided. Next, the energy was minimized, and the binding pocket of the protein was defined.

The 2D structures of the synthesized compounds and reference ligand (DAMA-colchicine) were sketched using ChemBioDraw Ultra 14.0 and saved as MDL-SD format. Then, the saved files were opened using MOE and 3D structures were protonated. Next, energy minimization was applied. Before docking process, validation of the docking protocol was carried out by running the simulation only using the co-crystallized ligand (DAMA-colchicine) which showed low RMSD value. The molecular docking of the synthesized was performed using a default protocol against the target receptor. In each case, 30 docked structures were generated using genetic algorithm 
searches, London dG was used for scoring and forcefield (MMFF94) for refinement. The London dG scoring function estimates the free energy of binding of the ligand from a given pose. The functional form is a sum of terms:

$$
\Delta G=c+E_{\mathrm{flex}}+\sum_{\text {h-bonds }} c_{\mathrm{HB}} f_{\mathrm{HB}}+\sum_{\mathrm{m} \text {-lig }} c_{\mathrm{M}} f_{\mathrm{M}}+\sum_{\text {atom i }} \Delta D_{\mathrm{i}}
$$

where $C$ represents the average gain/loss of rotational and translational entropy; $E_{\text {flex }}$ is the energy due to the loss of flexibility of the ligand (calculated from ligand topology only); FHB measures geometric imperfections of hydrogen bonds and takes a value in $[0,1] ; c_{\mathrm{HB}}$ is the energy of an ideal hydrogen bond; $f_{\mathrm{M}}$ measures geometric imperfections of metal ligations and takes a value in $[0,1] ; c_{M}$ is the energy of an ideal metal ligation; and $D_{\mathrm{i}}$ is the desolvation energy of atom $\mathrm{i}$.

The output from of MOE was further analyzed and visualized using Discovery Studio 4.0 software..$^{58-61}$

\section{Conflicts of interest}

This work was funded by the authors and there is no any conflict of interest.

\section{References}

1 S. Mukherjee, The emperor of all maladies: a biography of cancer, Simon and Schuster, 2010.

2 C. Holohan, S. Van Schaeybroeck, D. B. Longley and P. G. Johnston, Cancer drug resistance: an evolving paradigm, Nat. Rev. Cancer, 2013, 13, 714.

$3 \mathrm{H}$. Zahreddine and K. Borden, Mechanisms and insights into drug resistance in cancer, Front. Pharmacol., 2013, 4, 28.

4 M.-F. Chau, M. J. Radeke, C. de Inés, I. Barasoain, L. A. Kohlstaedt and S. C. Feinstein, The microtubuleassociated protein tau cross-links to two distinct sites on each $\alpha$ and $\beta$ tubulin monomer via separate domains, Biochem, 1998, 37, 17692-17703.

5 S. Honore, E. Pasquier and D. Braguer, Understanding microtubule dynamics for improved cancer therapy, Cell. Mol. Life Sci., 2005, 62, 3039-3056.

6 D. A. Fletcher and R. D. Mullins, Cell mechanics and the cytoskeleton, Nature, 2010, 463, 485.

7 E. A. Nigg, Cell division: mitotic kinases as regulators of cell division and its checkpoints, Nat. Rev. Mol. Cell Biol., 2001, 2, 21.

8 J. J. Field, A. Kanakkanthara and J. H. Miller, Microtubuletargeting agents are clinically successful due to both mitotic and interphase impairment of microtubule function, Bioorg. Med. Chem., 2014, 22, 5050-5059.

9 L. Wilson and M. A. Jordan, Microtubule dynamics: taking aim at a moving target, Chem. Biol., 1995, 2, 569-573.

10 K. Haider, S. Rahaman, M. S. Yar and K. Ahmed, Tubulin inhibitors as novel anticancer agents: an overview on patents (2013-2018), Expert Opin. Ther. Pat., 2019, 29(8), 623-641, DOI: 10.1080/13543776.2019.1648433.

11 M. Botta, S. Forli, M. Magnani, F. Manetti, Molecular modeling approaches to study the binding mode on tubulin of microtubule destabilizing and stabilizing agents, in Tubulin-Binding Agents, Springer, 2008, pp. 279328.

12 R. Altaha, T. Fojo, E. Reed and J. Abraham, Epothilones: a novel class of non-taxane microtubule-stabilizing agents, Curr. Pharm. Des., 2002, 8, 1707-1712.

13 A. E. Prota, K. Bargsten, J. F. Diaz, M. Marsh, C. Cuevas, M. Liniger, C. Neuhaus, J. M. Andreu, K.-H. Altmann and M. O. Steinmetz, A new tubulin-binding site and pharmacophore for microtubule-destabilizing anticancer drugs, Proc. Natl. Acad. Sci. U. S. A., 2014, 111, 13817-13821.

14 Y. Lu, J. Chen, M. Xiao, W. Li and D. D. Miller, An overview of tubulin inhibitors that interact with the colchicine binding site, Pharm. Res., 2012, 29, 2943-2971.

15 L. Li, S. Jiang, X. Li, Y. Liu, J. Su and J. Chen, Recent advances in trimethoxyphenyl (TMP) based tubulin inhibitors targeting the colchicine binding site, Eur. J. Med. Chem., 2018, 151, 482-494.

16 J. Zhou and P. Giannakakou, Targeting microtubules for cancer chemotherapy, Curr. Med. Chem., 2005, 5, 65-71.

17 G. R. Pettit, J. W. Lippert, D. L. Herald, E. Hamel and R. K. Pettit, Antineoplastic Agents 440. Asymmetric Synthesis and Evaluation of the Combretastatin A-1 SAR Probes (1 S, 2 S)-and (1 R, 2 R)-1, 2-Dihydroxy-1-(2 ', 3 '-dihydroxy-4 '-methoxyphenyl)-2-(3 “, 4 “, 5 "-trimethoxyphenyl)-ethane, J. Nat. Prod., 2000, 63, 969-974.

18 G. R. Pettit and J. W. Lippert, Antineoplastic agents 429. Syntheses of the combretastatin A-1 and combretastatin B1 prodrugs, Anti-Cancer Drug Des., 2000, 15, 203-216.

19 G. R. Pettit, J. C. Temple, V. Narayanan, R. Varma, M. Simpson, M. Boyd, G. Rener and N. Bansal, Antineoplastic agents 322. synthesis of combretastatin A-4 prodrugs, Anti-Cancer Drug Des., 1995, 10, 299-309.

20 I. G. Kirwan, P. M. Loadman, D. J. Swaine, D. A. Anthoney, G. R. Pettit, J. W. Lippert, S. D. Shnyder, P. A. Cooper and M. C. Bibby, Comparative preclinical pharmacokinetic and metabolic studies of the combretastatin prodrugs combretastatin A4 phosphate and A1 phosphate, Clin. Cancer Res., 2004, 10, 1446-1453.

21 S. A. Horner, S. Gould, J. P. Noakes, N. J. Rattray, S. L. Allen, E. Zotova and J. C. Arezzo, Lack of neurotoxicity of the vascular targeting agent ZD6126 following repeated iv dosing in the rat, Mol. Cancer Ther., 2004, 3, 783-791.

22 H. Goto, S. Yano, H. Zhang, Y. Matsumori, H. Ogawa, D. C. Blakey and S. Sone, Activity of a new vascular targeting agent, ZD6126, in pulmonary metastases by human lung adenocarcinoma in nude mice, Cancer Res., 2002, 62, 3711-3715.

23 K. R. Hande, A. Hagey, J. Berlin, Y. Cai, K. Meek, H. Kobayashi, A. C. Lockhart, D. Medina, J. Sosman and G. B. Gordon, The pharmacokinetics and safety of ABT751, a novel, orally bioavailable sulfonamide antimitotic agent: results of a phase 1 study, Clin. Cancer Res., 2006, 12, 2834-2840.

24 Z. Ding, H. Cheng, S. Wang, Y. Hou, J. Zhao, H. Guan and W. Li, Development of MBRI-001, a deuterium-substituted 
plinabulin derivative as a potent anti-cancer agent, Bioorg. Med. Chem. Lett., 2017, 27, 1416-1419.

25 G. K. Lloyd, P. Mueller, A. Zippelius and L. Huang, Abstract A07: Plinabulin: Evidence for an immune-mediated mechanism of action, Cancer Res., 2016, 76, A07.

26 A. V. Singh, M. Bandi, N. Raje, P. Richardson, M. A. Palladino, D. Chauhan and K. C. Anderson, A novel vascular disrupting agent plinabulin triggers JNK-mediated apoptosis and inhibits angiogenesis in multiple myeloma cells, Blood, 2011, 117, 5692-5700.

27 S. Kapoor, S. Srivastava and D. Panda, Indibulin dampens microtubule dynamics and produces synergistic antiproliferative effect with vinblastine in MCF-7 cells: Implications in cancer chemotherapy, Sci. Rep., 2018, 8, 12363.

28 G. Bacher, B. Nickel, P. Emig, U. Vanhoefer, S. Seeber, A. Shandra, T. Klenner and T. Beckers, D-24851, a novel synthetic microtubule inhibitor, exerts curative antitumoral activity in vivo, shows efficacy toward multidrug-resistant tumor cells, and lacks neurotoxicity, Cancer Res., 2001, 61, 392-399.

29 M. P. Tantak, L. Klingler, V. Arun, A. Kumar, R. Sadana and D. Kumar, Design and synthesis of bis (indolyl) ketohydrazide-hydrazones: Identification of potent and selective novel tubulin inhibitors, Eur. J. Med. Chem., 2017, 136, 184-194.

30 Y. Lu, J. Chen, J. Wang, C.-M. Li, S. Ahn, C. M. Barrett, J. T. Dalton, W. Li and D. D. Miller, Design, synthesis, and biological evaluation of stable colchicine binding site tubulin inhibitors as potential anticancer agents, J. Med. Chem., 2014, 57, 7355-7366.

31 A. Tripathi, D. Durrant, R. M. Lee, R. Baruchello, R. Romagnoli, D. Simoni and G. E. Kellogg, Hydropathic analysis and biological evaluation of stilbene derivatives as colchicine site microtubule inhibitors with anti-leukemic activity, J. Enzyme Inhib. Med. Chem., 2009, 24, 1237-1244.

32 T. L. Nguyen, C. McGrath, A. R. Hermone, J. C. Burnett, D. W. Zaharevitz, B. W. Day, P. Wipf, E. Hamel and R. Gussio, A common pharmacophore for a diverse set of colchicine site inhibitors using a structure-based approach, J. Med. Chem., 2005, 48, 6107-6116.

33 B. Bhattacharyya, D. Panda, S. Gupta and M. Banerjee, Anti-mitotic activity of colchicine and the structural basis for its interaction with tubulin, Med. Res. Rev., 2008, 28, 155-183.

34 D. Simoni, G. Grisolia, G. Giannini, M. Roberti, R. Rondanin, L. Piccagli, R. Baruchello, M. Rossi, R. Romagnoli and F. P. Invidiata, Heterocyclic and phenyl double-bondlocked combretastatin analogues possessing potent apoptosis-inducing activity in HL60 and in MDR cell lines, J. Med. Chem., 2005, 48, 723-736.

35 H. A. Mahdy, M. K. Ibrahim, A. M. Metwaly, A. Belal, A. B. Mehany, A. El-Sharkawy, M. A. Elhendawy, M. M. Radwan, M. A. Elsohly and I. H. Eissa, Design, synthesis, molecular modeling, in vivo studies and anticancer evaluation of quinazolin-4 $(3 \mathrm{H})$-one derivatives as potential VEGFR-2 inhibitors and apoptosis inducers, Bioorg. Chem., 2019, 103422.

36 A. G. A. El-Helby, H. Sakr, I. H. Eissa, A. A. Al-Karmalawy and K. El-Adl, Benzoxazole/benzothiazole-derived VEGFR-2 inhibitors: Design, synthesis, molecular docking, and anticancer evaluations, Arch. Pharm., 2019, e1900178.

37 I. H. Eissa, A. M. Metwaly, A. Belal, A. B. Mehany, R. R. Ayyad, K. El-Adl, H. A. Mahdy, M. S. Taghour, K. M. El-Gamal and M. E. El-Sawah, Discovery and antiproliferative evaluation of new quinoxalines as potential DNA intercalators and topoisomerase II inhibitors, Arch. Pharm., 2019, e1900123.

38 A. G. A. El-Helby, H. Sakr, I. H. Eissa, H. Abulkhair, A. A. Al-Karmalawy and K. El-Adl, Design, synthesis, molecular docking, and anticancer activity of benzoxazole derivatives as VEGFR-2 inhibitors, Arch. Pharm., 2019, 352, 1900113.

39 S. A. Elmetwally, K. F. Saied, I. H. Eissa and E. B. Elkaeed, Design, synthesis and anticancer evaluation of thieno [2, 3d] pyrimidine derivatives as dual EGFR/HER2 inhibitors and apoptosis inducers, Bioorg. Chem., 2019, 88, 102944.

40 M. Ibrahim, M. Taghour, A. Metwaly, A. Belal, A. Mehany, M. Elhendawy, M. Radwan, A. Yassin, N. El-Deeb and E. Hafez, Design, synthesis, molecular modeling and antiproliferative evaluation of novel quinoxaline derivatives as potential DNA intercalators and topoisomerase II inhibitors, Eur. J. Med. Chem., 2018, 155, 117-134.

41 A. A. Gaber, A. H. Bayoumi, A. M. El-morsy, F. F. Sherbiny, A. B. Mehany and I. H. Eissa, Design, synthesis and anticancer evaluation of $1 \mathrm{H}$-pyrazolo [3, 4-d] pyrimidine derivatives as potent EGFRWT and EGFRT790M inhibitors and apoptosis inducers, Bioorg. Chem., 2018, 80, 375-395.

42 I. H. Eissa, A. M. El-Naggar, N. E. El-Sattar and A. S. Youssef, Design and discovery of novel quinoxaline derivatives as dual DNA intercalators and topoisomerase II inhibitors, Anti-Cancer Agents Med. Chem., 2018, 18, 195-209.

43 A. M. El-Naggar, M. M. Abou-El-Regal, S. A. El-Metwally, F. F. Sherbiny and I. H. Eissa, Synthesis, characterization and molecular docking studies of thiouracil derivatives as potent thymidylate synthase inhibitors and potential anticancer agents, Mol. Divers., 2017, 21, 967-983.

44 W. M. Eldehna, M. F. Abo-Ashour, A. Nocentini, P. Gratteri, I. H. Eissa, M. Fares, O. E. Ismael, H. A. Ghabbour, M. M. Elaasser and H. A. Abdel-Aziz, Novel 4/3-((4-oxo-5-(2oxoindolin-3-ylidene) thiazolidin-2-ylidene) amino) benzenesulfonamides: Synthesis, carbonic anhydrase inhibitory activity, anticancer activity and molecular modelling studies, Eur. J. Med. Chem., 2017, 139, 250-262.

45 I. H. Eissa, A. M. El-Naggar and M. A. El-Hashash, Design, synthesis, molecular modeling and biological evaluation of novel $1 \mathrm{H}$-pyrazolo [3, 4-b] pyridine derivatives as potential anticancer agents, Bioorg. Chem., 2016, 67, 43-56.

46 A. M. El-Naggar, M. M. Hemdan and S. R. Atta-Allah, An Efficient One-Pot Synthesis of New Coumarin Derivatives as Potent Anticancer Agents under Microwave Irradiation, J. Heterocycl. Chem., 2017, 54, 3519-3526.

47 A. M. El-Naggar, A. K. Khalil, H. M. Zeidan and W. M. ElSayed, Eco-friendly Synthesis of Pyrido [2, 3-d] pyrimidine 
Analogs and Their Anticancer and Tyrosine Kinase Inhibition Activities, Anti-Cancer Agents Med. Chem., 2017, 17, 1644-1651.

48 K. A. Abouzid, G. H. Al-Ansary and A. M. El-Naggar, Ecofriendly synthesis of novel cyanopyridine derivatives and their anticancer and PIM-1 kinase inhibitory activities, Eur. J. Med. Chem., 2017, 134, 357-365.

49 T. Mosmann, Rapid colorimetric assay for cellular growth and survival: application to proliferation and cytotoxicity assays, J. Immunol. Methods, 1983, 65, 55-63.

50 F. Denizot and R. Lang, Rapid colorimetric assay for cell growth and survival: modifications to the tetrazolium dye procedure giving improved sensitivity and reliability, $J$. Immunol. Methods, 1986, 89, 271-277.

51 M. Thabrew, R. D. Hughes and I. G. Mcfarlane, Screening of hepatoprotective plant components using a HepG2 cell cytotoxicity assay, J. Pharm. Pharmacol., 1997, 49, 1132-1135.

52 G. M. Morris, D. S. Goodsell, R. S. Halliday, R. Huey, W. E. Hart, R. K. Belew and A. J. Olson, Automated docking using a Lamarckian genetic algorithm and an empirical binding free energy function, J. Comput. Chem., 1998, 19, 1639-1662.

53 J. Wang and M. J. Lenardo, Roles of caspases in apoptosis, development, and cytokine maturation revealed by homozygous gene deficiencies, J. Cell Sci., 2000, 113, 753757.

54 J. M. Brown and B. G. Wouters, Apoptosis, p53, and tumor cell sensitivity to anticancer agents, Cancer Res., 1999, 59, 1391-1399.

55 K. K.-W. Lo, T. K.-M. Lee, J. S.-Y. Lau, W.-L. Poon and S.-H. Cheng, Luminescent biological probes derived from ruthenium (II) estradiol polypyridine complexes, Inorg. Chem., 2008, 47, 200-208.

56 A. G. A. El-Helby, R. R. Ayyad, H. M. Sakr, A. S. Abdelrahim, K. El-Adl, F. S. Sherbiny, I. H. Eissa and M. M. Khalifa, Design, synthesis, molecular modeling and biological evaluation of novel 2, 3-dihydrophthalazine-1, 4-dione derivatives as potential anticonvulsant agents, J. Mol. Struct., 2017, 1130, 333-351.

57 M. I. Thabrew, R. D. Hughes and I. G. Mcfarlane, Screening of hepatoprotective plant components using a HepG2 cell cytotoxicity assay, J. Pharm. Pharmacol., 1997, 49, 1132-1135. 58 M. A. El-Zahabi, E. R. Elbendary, F. H. Bamanie, M. F. Radwan, S. A. Ghareib and I. H. Eissa, Design, synthesis, molecular modeling and anti-hyperglycemic evaluation of phthalimide-sulfonylurea hybrids as PPAR $\gamma$ and SUR agonists, Bioorg. Chem., 2019, 91, 103115.

59 M. K. Ibrahim, I. H. Eissa, M. S. Alesawy, A. M. Metwaly, M. M. Radwan and M. A. ElSohly, Design, synthesis, molecular modeling and anti-hyperglycemic evaluation of quinazolin-4 (3H)-one derivatives as potential PPAR $\gamma$ and SUR agonists, Bioorg. Med. Chem., 2017, 25, 4723-4744.

60 M. K. Ibrahim, I. H. Eissa, A. E. Abdallah, A. M. Metwaly, M. Radwan and M. ElSohly, Design, synthesis, molecular modeling and anti-hyperglycemic evaluation of novel quinoxaline derivatives as potential PPAR $\gamma$ and SUR agonists, Bioorg. Med. Chem., 2017, 25, 1496-1513.

61 K. M. El-Gamal, A. M. El-Morsy, A. M. Saad, I. H. Eissa and M. Alswah, Synthesis, docking, QSAR, ADMET and antimicrobial evaluation of new quinoline-3-carbonitrile derivatives as potential DNA-gyrase inhibitors, J. Mol. Struct., 2018, 1166, 15-33. 